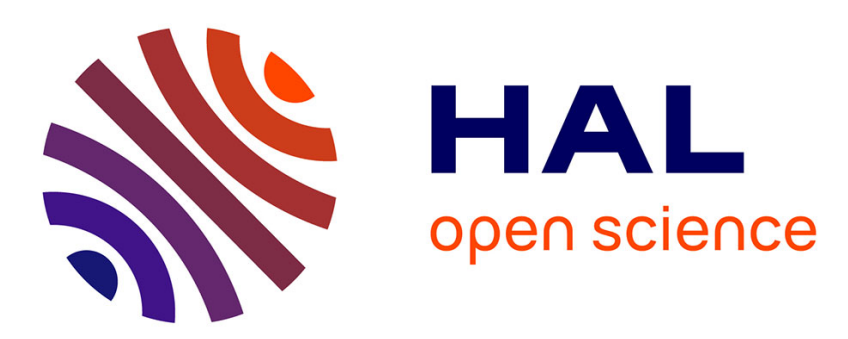

\title{
A general equilibrium evaluation of the sustainability of the new pension reforms in Italy
}

Riccardo Magnani

\section{To cite this version:}

Riccardo Magnani. A general equilibrium evaluation of the sustainability of the new pension reforms in Italy. Research in Economics, 2011, pp.5-35. halshs-00627727

\section{HAL Id: halshs-00627727 https://shs.hal.science/halshs-00627727}

Submitted on 29 Sep 2011

HAL is a multi-disciplinary open access archive for the deposit and dissemination of scientific research documents, whether they are published or not. The documents may come from teaching and research institutions in France or abroad, or from public or private research centers.
L'archive ouverte pluridisciplinaire HAL, est destinée au dépôt et à la diffusion de documents scientifiques de niveau recherche, publiés ou non, émanant des établissements d'enseignement et de recherche français ou étrangers, des laboratoires publics ou privés. 
No $2008-25$

November

\section{A General Equilibrium Evaluation of the Sustainability of the New Pension Reforms in I taly}

Riccardo Magnani 


\section{A General Equilibrium Evaluation of the Sustainability of the New Pension Reforms in Italy}

Riccardo Magnani

No 2008-25

November 


\section{TABLE OF CONTENTS}

$\begin{array}{lr}\text { 1. Introduction } & 8\end{array}$

$\begin{array}{ll}\text { 2. The Italian pension system } & 11\end{array}$

3. The model 13

3.1. General characteristics . . . . . . . . . . . . . . . . 13

3.2. The demographic evolution . . . . . . . . . . . . . . 16

3.3. The generations . . . . . . . . . . . . . . . 18

3.4. The government . . . . . . . . . . . . . . . 25

3.5. Equilibrium conditions . . . . . . . . . . . . . . . . . . 26

3.6. Dynamics of the economy $\ldots \ldots \ldots \ldots . \ldots 27$

4. Calibration of the model 27

4.1. The calibration of the pension system . . . . . . . . . . 27

4.2. The calibration of the macroeconomy . . . . . . . . . . . . 29

5. Effects of the recent reforms: Berlusconi and Prodi reforms 32

5.1. Macroeconomic impacts . . . . . . . . . . . . . . 32

5.2. Effects of the Berlusconi and Prodi reforms on the pension system . 35

5.3. Generational accounting . . . . . . . . . . . . . 41

6. Sensitivity analysis 43

6.1. Immigration . . . . . . . . . . . . . . 43

6.2. Pension benefits . . . . . . . . . . . . . 47

6.3. Small open economy . . . . . . . . . . . . . . . 50

7. Conclusions $\quad 55$ 


\section{A General Equilibrium Evaluation OF THE SUSTAINABILITY OF THE NeW Pension Reforms in Italy}

\section{NON-TECHNICAL SUMMARY}

Population ageing, determined by the increase in life expectancy, the reduction of fertility rates and, most of all, the baby-boom produced during the Fifties and Sixties, will be a common characteristic of most of all industrialized countries over the next decades. The aim of this paper is to provide an evaluation of the economic consequences of population ageing in Italy. The Italian case is a very interesting case for two reasons: first, in Italy, the demographic problem is one of the most serious in the world (only Japan will exhibit greater old-age dependency ratios, i.e. the ratio of the number of people aged 65 and more to the working age population); by considering that the Italian pension system is almost entirely composed of a compulsory public Pay-As-You-Go system, it will be extremely exposed to the demographic evolution; second, since 1992, many reforms have been introduced by the Italian governments in order to face the demographic problem: the Amato reform in 1992, the Dini reform in 1995, the Berlusconi reform in 2004 and the Prodi reform in 2007.

The Amato and the Dini reforms induce a strong reduction in the generosity of the Italian pension system by introducing (1) an indexation mechanism of pension benefits to prices instead of to real wages, (2) a new method of computation of pension benefits (contribution based method) where benefits are related to the contributions paid during the whole working life. Even if these reforms would induce a significant reduction in future pension benefits, they are generally considered not sufficient to face the ageing problem, in particular because of the too much long transition phase imposed by the Dini reform: in fact, the contribution based method will be completely applied after 2030. In 2004, the Berlusconi government introduced a new reform that increased the minimum retirement age to 60 from January 2008 onwards while, before the reform, individuals were free to retire at 57. In 2007, in particular given the strong opposition exerted by Italian's trade unions, the Prodi government replaced the Berlusconi reform with a softer one: the minimum retirement age is fixed at 58 from January 2008 and will gradually increase over time up to 62.

Using an overlapping-generations model, we first show that the reforms introduced in the Nineties imply a very important reduction in the replacement ratios. Thus, these reforms allow controlling the evolution of the pension expenditure by penalizing early retirement. Nevertheless, these reforms fail to ensure long-run solvability of the Italian pension system and, during the transition phase, the pension system would produce deficits higher than $3 \%$ of GDP. This implies that over the next decades, the level of taxation will significantly increase in order to reduce public deficits and thus fulfil Maastricht obligations. The analysis of the recent pension reforms shows that the increase in the retirement age induces a significant improvement of the financial conditions of the pension system only in the short and in the medium run. After 2035, the positive effect related to the increase in the labor supply, and then in contributions paid by the workers, is compensated by the increase in the value of 
pension benefits perceived by people forced to postpone retirement. In the long run, the increase in the retirement age has no positive impact on the financial conditions of the pension system and the pension deficit remains at about 1.7\% of GDP in 2055.

In Europe, even if pension systems remain essentially different, some similar measures have been introduced in order to reduce the pension expenditure burden: the indexation of pension benefits to prices, the increase in the retirement age and the increase of the role of private funding. In France, for example, the Fillon reform introduced in France in 2003 increases the number of years necessary to obtain the full replacement ratio. With respect to the Italian reform that increases the minimum retirement age, with the Fillon reform individuals are free to choose the retirement age. Moreover, the French reform avoids the problem related to the long-run inefficiency of the Berlusconi and Prodi reforms. In fact, with the French reform, if the employment rates of elder workers do not change, the reform permits a strong reduction in pension expenditure because of the application of a penalization while, if the employment rates of elder workers increase, the pension expenditure do not change and the contributions received by the government increase. In both cases, the French reform allows a permanent reduction in pension deficits. However, even if in the French case the demographic problem is less serious than in Italy, the Italian reforms are globally much more efficient that those introduced in France in order to control the evolution of pension expenditures. Of course, the cost associated to this greater efficiency is the strong reduction of the generosity of the Italian pension system produced by the Amato and Dini reforms.

\section{Abstract}

Most European countries have recently introduced pension system reforms to face the financial problem related to population ageing. Italy is not an exception. The reforms introduced during the Nineties (Amato Reform in 1992 and Dini Reform in 1995), even if they will produce a strong reduction in pension benefits, are generally thought not sufficient to adequately face the population ageing problem. For this reason, in 2004, the Berlusconi government introduced a new reform that increases the retirement age to 60 years from January 2008 onwards, to 61 years from 2010 and to 62 from 2014. In 2007, the left-wing government replaced this reform with a softer one that fixes the minimum retirement age at 58 from 2008. Using an applied overlapping-generations general equilibrium model, we analyze the impact of the new reforms on the macroeconomic system and in particular on the long-run sustainability of the pension system. We show that the increase in the retirement age would permit to reduce pension deficits in the short and medium run, while in the long run these reforms would become ineffective.

JEL Classification: D58, H55, J10.

Keywords: pension reforms, applied OLG models, immigration, endogenous growth. 


\section{EVALUATION DES NOUVELLES RÉFORMES DE RETRAITES EN ITALIE : UNE} APPROCHE D'ÉQUILIBRE GÉNÉRAL

\section{RESUME NON TECHNIQUE}

Le vieillissement démographique, provoqué par l'augmentation de l'espérance de vie, la baisse de la fécondité et le baby-boom des années 50 et 60, caractérisera les pays industrialisés dans les décennies futures. L'objectif de ce papier est d'évaluer les conséquences économiques du vieillissement démographique en Italie. Le cas italien est intéressant pour deux raisons. D'abord, la situation démographique en Italie est parmi les plus préoccupantes au monde (seule le Japon présente un taux de dépendance, c'est-à-dire le ratio entre le nombre de personnes âgées de plus de 65 ans sur la population en âge de travailler, plus élevé); le système de retraite italien reposant presque entièrement sur un système public par répartition, il sera très exposé au vieillissement. Ensuite, à partir de 1992, plusieurs réformes ont été mises en place : la réforme Amato en 1992, la réforme Dini en 1995, la réforme Berlusconi en 2004 et la réforme Prodi en 2007.

Les réformes Amato et Dini réduisent fortement la générosité du système de retraite en introduisant (1) un mécanisme d'indexation des retraites sur les prix, (2) un nouveau système de calcul des retraites où la valeur de la retraite est liée aux cotisations versées pendant toute la durée du travail. Même si ces réformes entraînent une baisse importante des pensions, elles sont généralement considérées comme insuffisantes pour équilibrer le système, en particulier à cause de la phase de transition très longue prévue par la réforme Dini. En 2004, le gouvernement Berlusconi a introduit une nouvelle réforme qui relève l'âge minimum de départ à la retraite alors que, avant cette réforme, il était possible de partir à la retraite à 57 ans. En 2007, en particulier à cause de la forte opposition des syndicats, le gouvernement Prodi a remplacé la réforme Berlusconi par une nouvelle réforme plus souple : l'âge minimum de départ à la retraite est fixé à 58 ans à partir de 2008 et augmentera progressivement jusqu'à 62 ans.

A l'aide d'un modèle d'équilibre général à générations imbriquées, nous montrons que les réformes introduites dans les années 90 conduisent à une baisse importante des taux de remplacement. Ces réformes permettent ainsi de contrôler les dépenses du système de retraite en pénalisant le départ à la retraite anticipé. Cependant, ces réformes n'assurent pas l'équilibre de long terme et, pendant la phase de transition, le système produit des déficits supérieurs à $3 \%$ du PIB. Cela impliquerait, dans les décennies futures, une augmentation considérable du niveau de taxation pour réduire les déficits publics et respecter les obligations de Maastricht. L'analyse des réformes récentes montre que l'augmentation de l'âge de départ à la retraite permet une amélioration significative de la situation financière du système de retraite uniquement dans les court et moyen termes. En revanche, après 2035, l'effet positif lié à l'augmentation de l'offre de travail et donc des cotisations versées est compensé par l'augmentation de la valeur des pensions perçues par les travailleurs qui retardent leur départ à la retraite. Ainsi, à long terme, l'augmentation de l'âge de départ à la retraite n'a pas d'effet sur la situation financière du système de retraite et, en 2055, le déficit reste de 1,7\% du PIB.

Ailleurs en Europe, même si les systèmes de retraite restent assez différents, la plupart des 
pays ont adopté des mesures similaires afin de limiter l'augmentation future des dépenses liées aux retraites : l'indexation des retraites aux prix, l'augmentation de l'âge de départ à la retraite, l'augmentation du rôle des fonds de pension. En France, par exemple, la réforme Fillon introduite en 2003 prévoit l'augmentation du nombre d'années nécessaires pour obtenir une retraite au taux plein. Par rapport à la réforme italienne qui augmente l'âge minimum de départ à la retraite, la réforme Fillon a d'abord l'avantage de laisser la liberté aux travailleurs de choisir la date de leur départ à la retraite. De plus, elle permet d'éviter le problème d'inefficacité de long terme des réformes Berlusconi et Prodi. En fait, avec la réforme française, si les taux d'emploi des seniors ne se modifient pas, la réforme permet une baisse considérable des dépenses grâce à l'application de la décote ; si, par contre, les taux d'emploi des seniors augmentent, les dépenses du système de retraite restent identiques et les cotisations perçues par les caisses de retraite augmentent; dans les deux cas, la réforme française permet de réduire de façon permanente les déficits du système de retraite. Cependant, même si dans le cas français le problème démographique est moins aigu qu'en Italie, les réformes introduites en Italie sont nettement plus efficaces que celles introduites en France du point de vue de l'évolution des dépenses du système de retraite. Evidemment, le coût associé à cette plus grande efficacité est la forte réduction de la générosité du système de retraite italien suite aux réformes Amato et Dini.

\section{RESUME COURT}

La plupart des pays européens ont récemment introduit des réformes du système de retraite pour faire face au problème financier lié au vieillissement démographique. L'Italie n'est pas une exception. Les réformes introduites dans les années 90 (réforme Amato en 1992 et réforme Dini en 1995), même si elles produisent une baisse considérable des pensions, sont généralement considérées comme insuffisantes. Pour cette raison, en 2004, le gouvernement Berlusconi a introduit une nouvelle réforme qui augmente l'âge de départ à la retraite à 60 ans à partir de 2008, à 61 ans à partir de 2010 et à 62 ans à partir de 2014. En 2007, le gouvernement Prodi a remplacé la réforme précédente par une plus souple qui augmente l'âge de départ à la retraite à 58 ans à partir de 2008. A l'aide d'un modèle OLG, nous analysons l'impact des nouvelles réformes sur le système macroéconomique et sur la soutenabilité du système de retraite. Nous montrons que l'augmentation de l'âge de départ à la retraite permet de réduire considérablement les déficits du système de retraite à court et à moyen terme, alors qu'à long terme ces réformes deviennent inefficaces.

Classification JEL : D58, H55, J10

Mots clés : réformes du système de retraite, modèles OLG, immigration, croissance endogène. 


\section{A General Equilibrium evaluation of the New Pension REFORMS IN ITALY}

Riccardo MAgnani ${ }^{1}$

\section{INTRODUCTION}

Industrialized countries will know a phase of significant demographic changes over the next 50 years. The increase in life expectancy, the reduction of fertility rates and, most of all, the baby-boom produced during the Fifties and Sixties have induced a population ageing that will put the financing of the social security systems under considerable stress. Italian demographics are quite representative of this largely European phenomenon. The demographic projections based on the central hypothesis presented by Istat (2006) show that the working age population - the number of people between 20 and 64 - will drop by $23 \%$ between 2000 and 2050 (Figure 1) and the old-age dependency ratio - the ratio of the number of people aged 65 and more to the working age population - will increase from $28.9 \%$ in 2000 to $68.1 \%$ in 2050 (Figure 2).

Figure 1: Working age population. Source: Istat, 2006

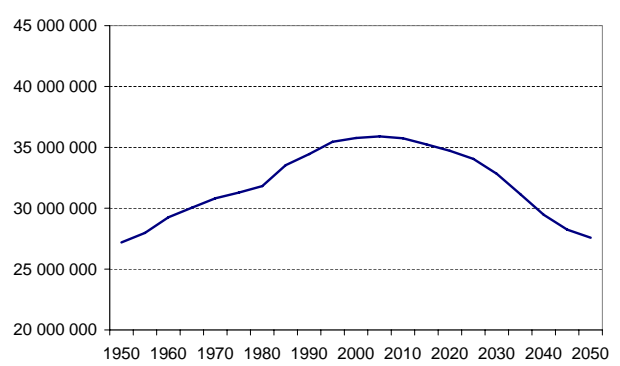

Figure 2: Old-age dependency ratio. Source: Istat, 2006

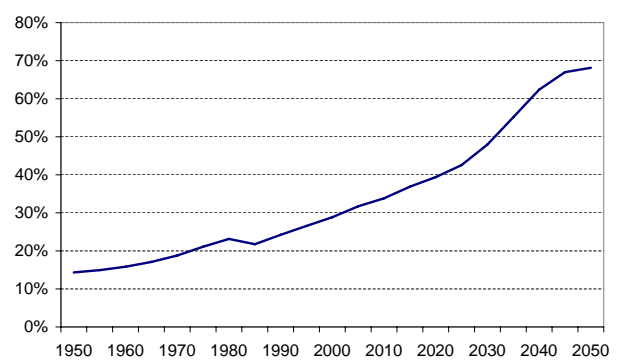

To face this problem, most European countries have recently introduced pension system reforms. Even if European pension systems remain essentially different, some similar measures have been introduced in order to reduce the pension expenditure burden: the indexation of pension benefits to prices, the increase in the retirement

${ }^{1}$ CEPII (riccardo.magnani@ cepii.fr). I am grateful to Agnès Benassy-Quéré and Martine Carré for useful comments. The usual disclaimer applies. 
age and the increase of the role of private funding. However, the pay-as-you-go system is still largely the most important pillar of European pension systems.

During the Nineties, two reforms of the pension system were implemented in Italy, the Amato reform (1992), and the Dini reform (1995). Even if these reforms would induce a significant reduction in future pension benefits, they are unanimously regarded as being non sufficient in the medium run - because of the long transition phase imposed by the Dini reform that will produce important social security deficits - as well as in the long run: even when completely applied, the reforms cannot be expected to achieve the financial equilibrium of the pension system. ${ }^{2}$ In addition, the impacts on the macroeconomic system are likely to be negative: pension system deficits generate a fall in national savings, reduce capital accumulation and slow down economic growth.

As a consequence, a new pension system reform seemed inevitable and in 2004, the Berlusconi government decided to increase the minimum retirement age to 60 from January 2008 onwards. The Berlusconi reform, even if it would produce a significant reduction of the pension expenditures in the short term, has been considered deeply unfair with respect to the generations born after 1948. For this reason, and given the pressure exerted by Italian's trade unions, the left-wing Prodi government replaced in 2007 the Berlusconi reform with a softer one: the minimum retirement age is fixed at 58 from January 2008, and it will gradually increase over time up to 62.

The aim of this paper is to evaluate and compare the Berlusconi and the Prodi reforms. We evaluate the effects on the pension system and on the macroeconomy of the increase in the retirement age proposed by the new reforms. We show that the Prodi reform induces an important reduction in pension deficits in the medium run, but less important than the reduction that could be induced by the Berlusconi reform. However, these two new reforms become completely ineffective in the long run.

Our assessment is based on simulation exercises using an applied overlapping-generations general equilibrium model. A dynamic general equilibrium perspective is indeed required in order to evaluate the effects of pension reforms on the macroeconomy and on the pension system, since population ageing will significantly affect labor supply (and thus the evolution of wages) and capital accumulation (and thus the evolution of investments, interest rates and GDP). The evolution of wages directly affects the evo-

\footnotetext{
${ }^{2}$ A partial equilibrium analysis carried out by the Italian Ministry of Labor and Social Policies (Nucleo di Valutazione della Spesa Previdenziale, 2006) shows that, even by considering very optimistic assumptions (the revision of the transformation coefficients, a $1.8 \%$ long run productivity growth rate, and an increase in the employment rate of people $15-64$ from $57.5 \%$ in 2005 to $67.9 \%$ in 2050), the ratio of pension expenditures to GDP will deeply increase in the period 2010-2035, then it decreases and in 2050 the ratio displays the same value as in 2005 .
} 
lution of social security contributions, whereas the evolution of GDP growth rates, with the application of the Dini reform, affects the evolution of pension benefits.

The model used in this paper is of the type pioneered by Auerbach and Kotlikoff (1987), though with significant differences: we introduce mortality, immigration, human capital accumulation, and endogenous growth. The introduction of mortality and immigration makes it possible to accurately reproduce the demographic projections and to simulate the effects of changes in immigration flows. The introduction of human capital makes it possible to introduce a mechanism of endogenous growth based on the average level of knowledge present in the economy à la Lucas (1988). Human capital accumulation results from explicit decision making by young people to invest time in education.

An important aspect related to population ageing is the effects of demographic change and pension reforms on education decisions and consequently on economic growth. ${ }^{3}$ Indeed, relative factor prices are likely to vary significantly in the next decades hence affecting the decision to invest or not in human capital. One can expect that the impact of population ageing on human capital formation will be positive, since ageing would boost wages and reduce interest rates, and that the increase in retirement age would encourage individuals to devote more time to schooling. The positive impact on economic growth could be important ${ }^{4}$ and, as a consequence, produce positive effects on the financial situation of the pension system.

Our model treats Italy as a closed economy. The degree of the financial openness is a very important aspect (see Börsch-Supan (2006), Aglietta et al. (2007), Chateau et al. (2008)) since it affects the determination of the interest rate that affects the evolution of the public debt, the evolution of capital accumulation, the economic growth, and so on. By considering that ageing is a worldwide phenomenon, assuming a fixed and constant interest rate would be misleading. This is why we preferred to consider Italy as a closed economy in order to generate an endogenous interest rate that is compatible with a world ageing context. However, when considering a specific pension reform in Italy, the world interest rate can be considered exogenous. For this reason, in the last section, we did a robustness check in which we consider Italy as a small open economy where the interest rate is fixed at the level computed in the benchmark case.

The paper is organized as follows: in the next section, we describe the characteristics of the Italian pension system and the reforms recently introduced. In sections 3 and

\footnotetext{
${ }^{3}$ Other OLG models including an endogenous growth mechanism based on human capital are provided by Fougère and Mérette (1999), Sadahiro and Shimasawa (2003) and Bouzahzah et al. (2002).

${ }^{4}$ people aged 25 and more induces an increase in the economic growth rate of $0.44 \%$ per year.
} 
4, we describe the structure of the OLG model and its calibration. Section 5 presents the simulation results concerning the Berlusconi and the Prodi reforms. Section 6 presents some sensitivity analysis concerning the immigration, the value of pension benefits and the hypothesis of financial openness. We draw our conclusions in the last section.

\section{THE ITALIAN PENSION SYSTEM}

The Italian pension system is almost entirely composed of a compulsory public PayAs-You-Go system. An important anomaly of the Italian pension system is that there is no clear separation between the pension system in its strict sense and the system of social aids in which benefits are not related to contributions. In particular, the Italian pension system includes pensions related to work (old-age pensions, disability pensions, pensions paid in the case of occupational diseases and industrial injuries), and other pensions (survival pensions, and welfare benefits for people aged 65 and more lacking adequate means of support). In particular, in 2005: ${ }^{5}$

- IVS pensions (old-age pensions, pensions to survivors and disability benefits) accounted for $13.64 \%$ of GDP with 18.383 millions pensions paid. The average pension benefit was 10557 euros.

- Pensions paid in the case of occupational diseases and industrial injuries accounted for $0.30 \%$ of GDP with one million pensions paid. The average pension benefit was 4132 euros.

- Social assistance pensions (for people aged 65 and more lacking adequate means of support) accounted for $1.16 \%$ of GDP with 3.841 millions pensions paid. The average pension benefit was 4306 euros.

- Total pensions then accounted for $15.10 \%$ of GDP with 23.257 millions pensions paid. The average pension benefit was 9239 euros.

During the Nineties two reforms were introduced in order to reduce future total pension expenditures and to harmonize the different pension regimes: ${ }^{6}$ the Amato reform in 1992 and the Dini reform in 1995.

\footnotetext{
${ }^{5}$ Istat (2007), Statistiche della previdenza e dell'assistenza sociale. I trattamenti pensionistici. Anno 2005 .

${ }^{6}$ Until 1992 the Italian pension system was characterized by a very large number of funds and schemes, in which contributions and benefit rules varied according to the sector (private or public sector, or self-employment). The harmonization process of the different pension regimes, in particular concerning public and private employees, was accelerated by the Law 449/1997.
} 
The most important innovations of the Amato reform (Law 421/1992) were (i) the indexation of pension benefits on inflation, and not on real wages; $;^{7}$ (ii) the increase of the age requirement to be entitled to an old-age pension from 60 for men and 55 for women with at least 15 years of contributions to 65 for men and 60 for women with at least 20 years of contributions.

The Dini reform (Law 335/1995) introduced the following rules for the computation of the pension benefits:

- For people who started working after 1995, the pension benefits are computed according to a new rule: the contribution based method. In this case, the contributions paid during the whole working life are virtually capitalized at the average rate of growth of nominal GDP; the value of the pension is equal to the capitalized value of the contributions multiplied by a transformation coefficient depending on the retirement age.

- For people who had more than 18 years of contributions in 1995, the pension benefits remain computed according to the earning based method, i.e. on the basis of the average of the labor incomes earned during the 10 last years for salaried workers and the 15 last years for self-employed workers.

- For people who in 1995 totalized less than 18 years of contributions, the pension benefits are computed according to the pro-rata method. In this case, the pension benefits are given by a weighted average of the pension computed with the earning based method and the contribution based method.

With the Dini reform, the eligibility requirements to be entitled to a seniority pension were set as follows:

- For salaried workers aged more than 57, 35 years of contributions are required;

- For self-employed workers, 40 years of contributions are required; and it is reduced to 35 years of contributions if the person is more than 58 .

Workers can thus decide to retire at 57, with at least 35 years of contributions. The main goal of the Dini reform was to penalize early retirement. In fact, with the contribution based method, if an individual works less the value of pension benefits will be lower since he/she accumulates a lower amount of contributions and the transformation coefficient applied will be also lower.

\footnotetext{
${ }^{7}$ This reform allows important reduction in pension expenditures especially in periods with sustained economic growth since contributions grow at a high rate while pension benefits paid to people already retired remain constant in real terms.
} 
In 2004, the Berlusconi government introduced a new reform (Law 243/2004) that increased the minimum retirement age. According to this reform, the eligibility requirements would become 40 years of contributions or 35 years of contributions at the age of 60 for salaried workers and 61 for self-employed workers starting from 2008. The minimum retirement age would be increased by one year in 2010 and by another year in 2014.

The Berlusconi reform was replaced by the one introduced by the Prodi government in 2007 (Law 247/2007). With the new reform, the increase of the minimum retirement age is more gradual: in 2008, the minimum retirement age for salaried workers is 58 with at least 35 years of contributions. From 2009 onwards, the eligibility requirements are related to the sum of the retirement age and the number of years of contributions. In 2009, salaried workers aged no less than 59 can retire if the sum is equal to 95 . In 2011, salaried workers aged no less than 60 can retire if the sum is equal to 96. From 2013 onwards, salaried workers aged no less than 61 can retire if the sum is equal to 97 . For self-employed workers, the minimum retirement age is given by the minimum retirement age for salaried workers plus one year. Table 1 summarizes the aspects of the Berlusconi reform and Prodi reforms.

The reforms introduced until now harmonized the pension schemes for public and private salaried workers. In contrast, the rules applied to self-employed workers remain different, not only in terms of the eligibility requirements, but also in terms of social contribution rates. For instance, the contribution rate of salaried workers in the public and private sectors is equal to $33 \%$, while for self-employed workers it is quite lower and equals $20 \%$.

Finally, the Amato and the Dini reforms have introduced and improved the legislation on supplementary funded schemes. Nevertheless, the number of workers enrolled in private pension funds remains very low.

\section{THE MODEL}

\subsection{General characteristics}

The model presented in this paper is an applied overlapping-generations model of the type Auerbach-Kotlikoff (1987) with endogenous growth and immigration. We consider 15 age groups, indicated by $g=1, \ldots, 15$, that coexist at each period $t$. The first age group considered is 20-24, the last one is 90-94. Each period consists of 5 years and all the variables are supposed to be constant during each period.

For each age group, individuals are characterized by their origin and their profes- 
Table 1: Main aspects of the Berlusconi reform (Law 243/2004) and Prodi reform (Law 247/2007)

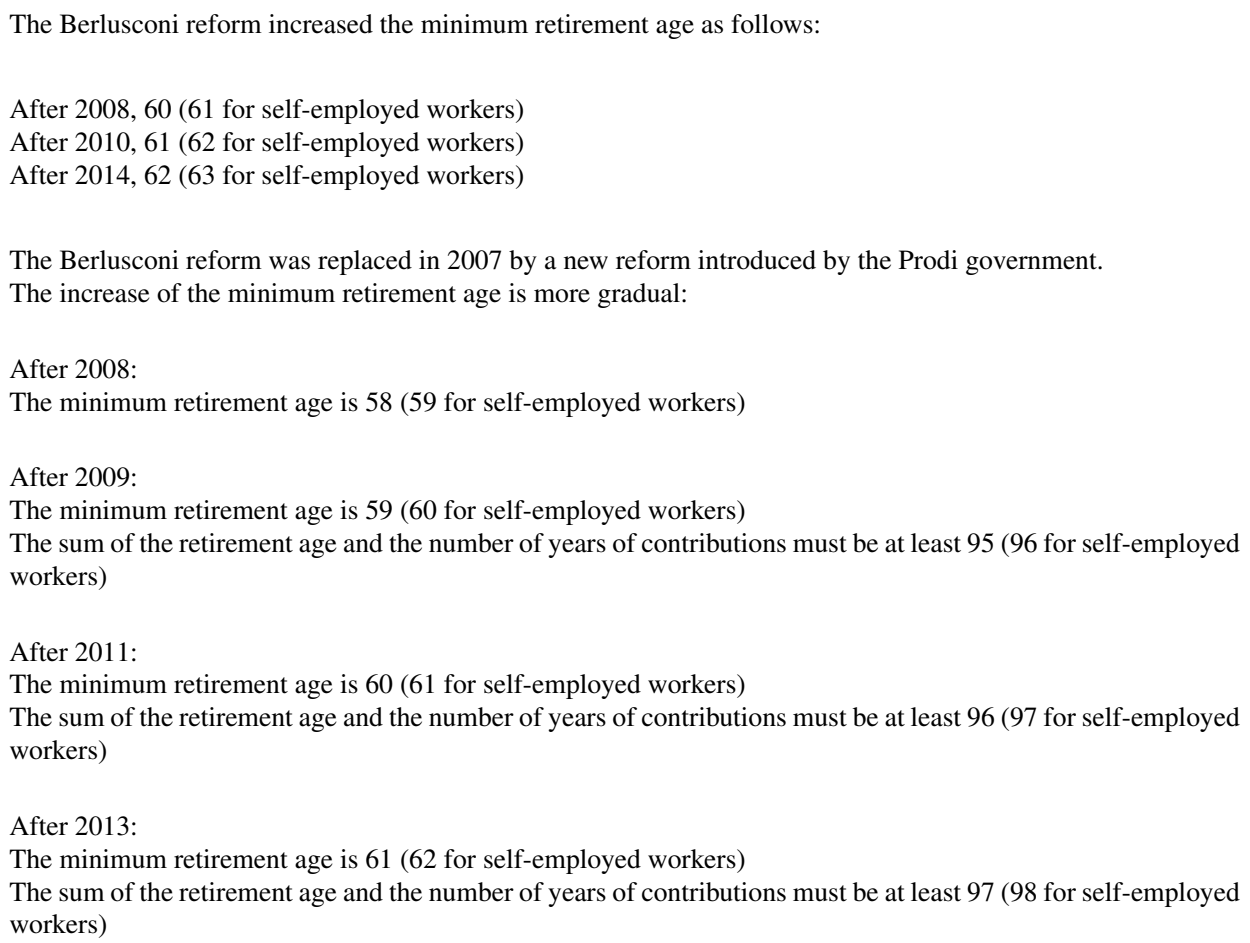

sional status. Concerning the origin, we distinguish two groups, indicated by $z$ : those born in Italy (nat) and immigrants $(\mathrm{imm}) .{ }^{8}$ Concerning the professional status, we distinguish two groups, indicated by prof, the salaried workers (prof $=e m p l$ ) and the self-employed workers ( $p r o f=\operatorname{self}$ ).

We assume that the existence of a representative agent of people born in Italy and a representative agent of immigrants (intra-generation's heterogeneity), and we assume that agents have perfect foresight and there is no liquidity constraint.

At the end of each period, people belonging to the last age group $(g=15)$ die, a

\footnotetext{
${ }^{8} \mathrm{We}$ assume that immigration only concerns the age group 30-34. This assumption is justified by the fact that data concerning resident permits (Istat, 2004) are normally distributed with a peak for the age group 30-34. In any case, the introduction into the model of immigration at different age does not significantly change the results.
} 
fraction of people belonging to the other classes dies, and a new generation enters the active population.

Individuals maximize an intertemporal utility function subject to an intertemporal budget constraint. Immigrants and people born in Italy have the same structure of preferences. They decide the intertemporal profile of consumption and leisure as well as the value of the voluntary bequests that will be left at the end of the last period of life. On the other hand, only people born in Italy decide the fraction of time to devote to studying. This decision allows the individual to constitute a stock of human capital that affects his/her productivity level and then his/her future earning profile. We introduce an endogenous growth mechanism à la Lucas (1988) where the productivity growth rate is related to the average level of knowledge present in the economy.

Intra-generation's heterogeneity is given by the assumption that immigrants differ from people born in Italy by a lower level of productivity and that they enter Italy with no capital. On the other hand, the children of immigrants are considered identical to the children of people born in Italy. Consequently, they decide the fraction of time to devote to studying and they display the same productivity as the children of natives.

People who die in the last period of life (95 years old) decide to leave bequests to the other generations, on the basis of the maximization of their utility function. These voluntary bequests are uniformly distributed among the other generations. On the other hand, the presence of involuntary bequests is avoided by introducing an insurance mechanism à la Yaari (1965).

Concerning the production side of the model, in our economy, only one good is produced by using labor and capital in order to maximize profits and given the following Cobb-Douglas technology:

$$
Y_{t}=K_{t}^{\alpha} \cdot L_{t}^{1-\alpha}
$$

where $Y_{t}$ represents the production level of the period, $K_{t}$ the physical capital demand, and $L_{t}$ the per unit of effective labor demand. Labor and capital markets are assumed to be perfectly competitive. This implies that real wages and real interest rates adjust to equilibrate aggregate demand and aggregate supply.

Aggregate capital supply depends on the individual's capital accumulation, while aggregate labor supply depends on the demographic evolution and on the individual's labor market choices. Labor is supplied by salaried workers and self-employed workers aged between 20 and 64. Labor supply is endogenous for people aged between 20 and 54. In particular, people belonging to the first age group (20-24 years old) decide the fraction of time to devote to the accumulation of human capital and to work. The following age groups, until the class 50-54, decide the fraction of time to 
devote to working and to leisure. With regard to the two last age groups who work (55-59 and 60-64), the fraction of people who work is exogenously fixed, according to the 2005 data. This permits us to simulate the impact of an exogenous increase in the retirement age.

The distinction between (private and public) salaried workers and self-employed is introduced in the model because the social contribution rates, the computation rule of pension benefits and the eligibility criteria are different. Thus, it is important to distinguish individuals according to their professional status in order to model the pension system accurately. However, we do not explicitly model the choice of the professional status, and we simply assume that the proportion of salaried workers and self-employed workers is the same for each group and remains constant over time.

In the next paragraphs, we describe in more detail the demographic aspects of the model (i.e. the procedure adopted in order to reproduce the demographic projections by selecting the fertility rates, the survival probabilities and the immigration flows), the generations' behavior and the government budget, focusing in particular on the pension system.

\subsection{The demographic evolution}

The first step of our modeling effort is to reproduce the demographic projections presented by Istat (2006) for the period 1950-2050. In particular, since only people aged 20 and more are taken into account in the model, ${ }^{9}$ our objective is to reproduce the demographic evolution of the population aged 20 and more, and in particular the old-age dependency ratio, i.e. the ratio between people aged 65 and more and people between 20 and 64, the structure of the population, i.e. the ratio between the number of people belonging to a specific age group and the total population, and the total population aged more than 20 .

For the first nine age groups we used the survival rates presented by Istat (2006), while the survival probabilities for the other age groups and the fertility rates have been calibrated in order to reproduce the Italian demographic evolution. In particular, following Istat (2007), immigrants' fertility rates are supposed to be twice those of natives. We assume that the fertility rates of the second-generation immigrants are identical of those of natives. ${ }^{10}$ Given the lack of data, we also assume that the survival rates are identical for the people born in Italy and immigrants. We adopt migratory

\footnotetext{
${ }^{9}$ People under 20 are supposed completely dependent of their family.

${ }^{10}$ Mayer and Riphahn (1999) estimated that the fertility rates of immigrants tend to converge to the fertility rates of the natives.
} 
flows of 150000 individuals per year since 1990, following Istat's assumptions.

The quality of the calibration of demographic variables to Istat's projections is summarized in the following figures where we report the old-age dependency ratio, the total population aged more than aged 20 and more and the weight of the different age classes in the total population. We can see that the quality of the fit is high.

Figure 3: Old-age dependency ratio

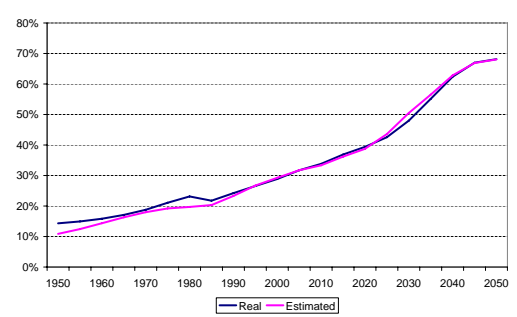

Figure 5: 20-34 / >20

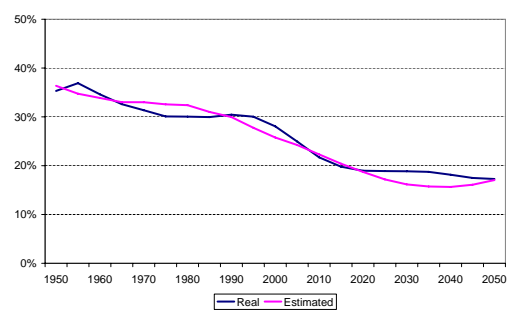

Figure 7: 50-64 / >20

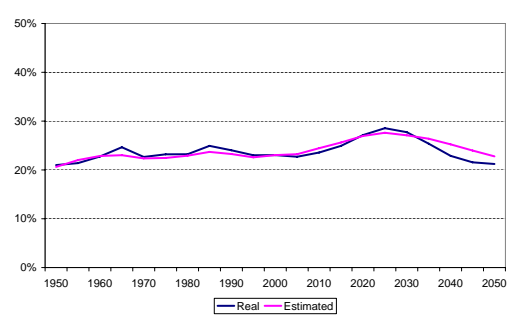

Figure 4: Total population

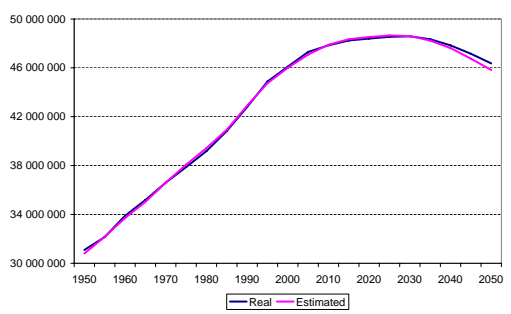

Figure 6: $35-49$ / >20

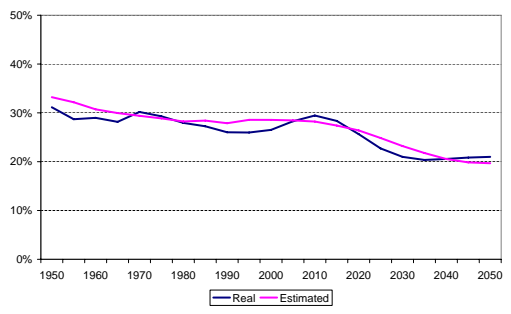

Figure 8: $>65$ / $>20$

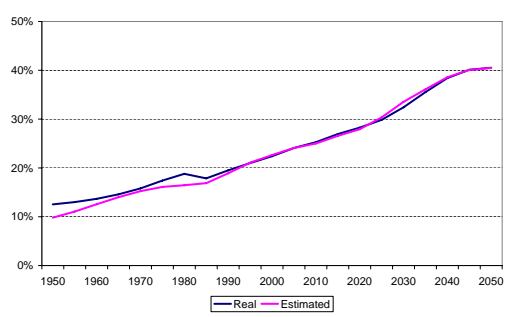




\subsection{The generations}

\subsubsection{Intertemporal preferences}

Natives $(z=n a t)$ and immigrants $(z=i m m)$ have the same structure of preferences. The expected lifetime utility for the generation of origin $z$ that becomes active in $t$ depends on the consumption profile, on the leisure profile and on the bequests left at the end of the last period of life, according to the following relation:

$$
\begin{aligned}
U_{t}^{z}= & \sum_{g} \Omega_{g, t+g-1} \cdot \Gamma_{g} . \\
& \left\{\frac{\left[c_{g, t+g-1}^{z}\right]^{\beta_{g}^{z}} \cdot\left[\Delta \cdot\left(1-l_{g, t+g-1}^{z}\right)\right]^{\beta_{L_{g}}^{z}} \cdot\left[b e q_{g, t+g-1}^{z}\right]^{\beta_{g}^{z}}}{1-\frac{1}{\gamma}}\right\}^{1-\frac{1}{\gamma}}
\end{aligned}
$$

where $1 \leq g \leq 15$ for natives and $3 \leq g \leq 15$ for immigrants since we assume that they enter Italy aged 30-34.

The following notations have been used:

$c_{g, t}^{z}$ is the consumption of individuals of origin $z$ and belonging to the age group $g ; l_{g, t}^{z}$ represents the fraction of time devoted to working; ${ }^{11}$ be $q_{15, t}^{z}$ is the voluntary bequests left at 95 years old.

$\Gamma_{g}$ is the actualization factor $\left(\Gamma_{g}=\prod_{s=1}^{g} \frac{1}{1+\rho_{s}}\right.$, where $\rho_{g}$ is the intertemporal preference rate for an individual belonging to the age class $g$ ); $\Delta$ stands for the number of years that constitute one period (5 years); $\Omega_{g, t}$ is the probability that an individual who belongs to the age group $g$ is alive in $t ; \gamma$ is the intertemporal elasticity, while the intra-temporal elasticity is assumed to be equal to 1 .

$\beta_{C_{g}}^{z}, \beta_{L_{g}}^{z}$ and $\beta_{B_{g}}^{z}$ measure respectively the intensity of the preference for consumption, for leisure and for bequests. In particular:

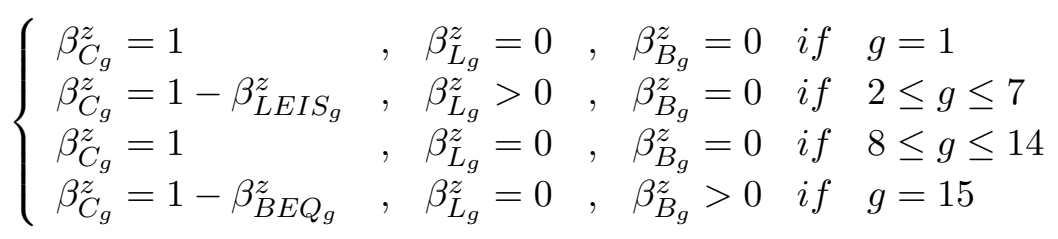

\subsubsection{Individual productivity and human capital accumulation}

The labor income for an individual of origin $z$, belonging to the age group $g$ and working in the professional activity prof, is given by the product between the wage

\footnotetext{
${ }^{11} 1-l_{g, t}^{z}$ represents the fraction of time devoted to leisure with $g>1$, whereas for the first age group $(g=1)$ it represents the fraction of time devoted to studying.
} 
per unit of effective labor $\left(w_{t}\right)$ and the total productivity level specific to the individual $\left(A_{g, t}^{z, p r o f}\right)$.

In particular, the wage per unit of effective labor, identical for each individual, is endogenously determined in order to guarantee the labor market equilibrium, see Equation (24).

The individual productivity level depends on five elements:

i) The individual's age, measured by $E P_{g}$. This component exerts a standard quadratic form:

$$
E P_{g}=\theta_{0}+\theta_{1} g+\theta_{2} g^{2}
$$

with $1 \leq g \leq 9$ since only people in the first nine age groups work, and $\theta_{1}>0, \theta_{2}<0$.

ii) The individual's education level, measured by $H C_{g, t}^{z}$. The stock of human capital accumulated by natives $(z=n a t)$ belonging to the first age group (20-24) depends on the number of years devoted to studying according to the following increasing and concave relation:

$$
H C_{1, t}^{n a t}=\left[\Delta \cdot\left(1-l_{1, t}^{n a t}\right)\right]^{\alpha_{H C}}
$$

where $\left[\Delta \cdot\left(1-l_{1, t}^{n a t}\right)\right]$ is the number of years devoted to studying and $\alpha_{H C}>$ 0 . Afterwards, the individual human capital depreciates at a constant rate $\delta_{H C}$ :

$$
H C_{g, t}^{n a t}=\left(1-\delta_{H C}\right) \cdot H C_{g-1, t-1}^{n a t}
$$

Given that immigrants enter Italy aged 30-34, they are not concerned by the choice of the education level, then their human capital stock $\left(H C_{g, t}^{i m m}\right)$ is considered exogenous.

iii) An externality component, measured by $H_{t}$, related to the average level of knowledge present in the economy, indicated by $\bar{H}_{t}$. This latter component is given by the weighted average of the stocks of human capital of each age class that works at the same period: $\bar{H}_{t}=\frac{\sum_{z} \sum_{g} H C_{g, t}^{z} \cdot l_{g, t}^{z} \cdot P_{o p}^{z}}{\sum_{z} \sum_{g} l_{g, t}^{z} \cdot P_{0} p_{g, t}^{z}}$. Moreover, we introduce an endogenous growth mechanism $\grave{a}$ la Lucas (1988) in the following way: the productivity growth rate $\left(g_{H_{t}}\right)$, which represents the steady state growth rate of variables in per capita terms, is endogenous and supposed to be related to the average level of knowledge as follows:

$$
g_{H_{t}}=\frac{H_{t+1}-H_{t}}{H_{t}}=\chi \cdot \bar{H}_{t}^{\frac{1}{\alpha_{H C}}}
$$


where $\chi>0$. As no individual could influence, by his/her decision to study, the value of this index, this stands as a positive externality.

iv) The individual's professional status, measured by $\Psi^{\text {prof }}$, that represents the (exogenous and constant) difference in productivity between salaried workers and self-employed workers.

v) The individual's origins, measured by $\theta^{z}$, that represents the difference in productivity between natives and immigrants in the base year. ${ }^{12}$

Finally, the individual's total productivity $\left(A_{g, t}^{z, p r o f}\right)$ is given by the product of the previous elements:

$$
A_{g, t}^{z, p r o f}=E P_{g} \cdot H C_{g, t}^{z} \cdot H_{t} \cdot \Psi^{\text {prof }} \cdot \theta^{z}
$$

Given that the productivity difference between salaried workers and self-employed workers is assumed to be constant and that the individual choice between these two options is not modeled, we can define an average productivity, indicated by $A_{g, t}^{z}$. This element is computed as the average of $A_{g, t}^{z, p r o f}$ weighted by the proportion (assumed to be the same for each age group and constant over time) of salaried workers and self-employed workers.

\subsubsection{Pension benefits}

Pension benefits are computed according to the rules introduced by the reforms Amato and Dini. In our analysis, we consider three types of pensions, indicated by type: direct pensions $($ type $=d i r)$, disability benefits $($ type $=d i s)$ and pensions to survivors $($ type $=$ surv). These pensions are paid to the retirees according to their professional status prof, i.e. to salaried workers (prof $=e m p l$ ) and self-employed workers (prof $=$ self). We begin with the description of the computation of direct pensions.

The value of direct pension benefits is computed in the model by applying the earning based method for the pensions paid until 2015, the pro-rata method for the pensions paid between 2015 and 2030, and the contribution based method for the pensions paid from 2030.

First of all, it is necessary to distinguish pension benefits paid to individuals belonging to the age group 55-59 and to individuals belonging to the age group 60-64. For

\footnotetext{
${ }^{12}$ However, note that the difference in productivity between natives and immigrants may change over time since the human capital stock of natives is endogenous.
} 
the latter, only a fraction of people retires between 60 and 64 while the complement fraction retires during the previous period (55-59).

For the retirees belonging to the age group 55-59 $(g=8)$, pension benefits are computed in the following way:

- Earning based method $(t<2015)$ : the annual pension benefit is computed on the basis of the average income earned during the last 10 years (the last two periods in our model) for salaried workers ( $p r o f=e m p l)$ and during the last 15 years (the last three periods in our model) for self-employed workers (prof $=$ self):

$$
\begin{aligned}
\text { Pens }_{8, \text { dir }, t}^{z, e m p l} & =n_{8}^{z} \cdot 0.02 \cdot \frac{\sum_{s=0}^{1} w_{t-s} \cdot A_{8-s, e m p l, t-s}^{z, \text { empl }}}{2} \\
\text { Pens } s_{8, \text { dir }, t}^{z, \text { self }} & =n_{8}^{z} \cdot 0.02 \cdot \frac{\sum_{s=0}^{2} w_{t-s} \cdot A_{8-s, e m p l, t-s}^{z, \text { empl }}}{3}
\end{aligned}
$$

The replacement ratio is then proportional to the number of years worked by class 55-59, indicated by $n_{8}^{z}$.

- Contribution based method ( $t>2030)$ : the annual pension benefit for each professional status (salaried workers and self-employed) is computed by multiplying the transformation coefficient $\beta_{8}$ by the value of the contributions paid during the whole working life and capitalized on the basis of the average GDP growth rate $\left(g_{g d p_{t}}\right)$ :

$$
\operatorname{Pens}_{8, \text { dir }, t}^{z, \text { prof }}=\beta_{8} \cdot\left(\sum_{g} \tau^{c} \cdot w_{t+g-8} \cdot A_{g, t+g-8}^{z, \text { prof }} \cdot \prod_{s=t+g-8}^{t}\left(1+g_{g d p_{s}}\right)\right)
$$

with $1 \leq g \leq 8$ for people born in Italy and $3 \leq g \leq 8$ for immigrants.

- Pro-rata method (2015 $\leq t \leq 2030$ ): the annual pension benefit is equal to a weighted average between the pension benefit computed with the earning based method and the contribution based method, where the weight depends on the number of years worked before and after 1995 .

For the retirees belonging to the age group 60-64 $(g=9)$, we have to consider that only a fraction (noted $\lambda$ ) of these individuals retires between 60 and 64 and that the complement fraction $(1-\lambda)$ retires during the previous period (55-59). On average, the pension benefit obtained by the representative individual aged 60-64 is computed in the following way: 
- Earning based method $(t<2015)$ : the annual pension benefit for salaried workers and self-employed workers is given by:

$$
\begin{aligned}
\text { Pens }_{9, \text { dir }, t}^{z, \text { empl }}= & \lambda \cdot n_{9}^{z} \cdot 0.02 \cdot \frac{\sum_{s=0}^{1} w_{t-s} \cdot A_{9-s, e m p l, t-s}^{z, \text { empl }}}{2} \\
& +(1-\lambda) \cdot \text { Pens }_{8, \text { empl }, t-1}^{z, \text { empl }} \\
\text { Pens }_{9, \text { dir }, t}^{z, \text { self }}= & \lambda \cdot n_{9}^{z} \cdot 0.02 \cdot \frac{\sum_{s=0}^{2} w_{t-s} \cdot A_{9-s, e m p l, t-s}^{z, \text { empl }}}{3} \\
& +(1-\lambda) \cdot \text { Pens }_{8, t-1}^{z, \text { self }}
\end{aligned}
$$

- Contribution based method $(t>2030)$ :

$$
\begin{aligned}
\text { Pens }_{9, \text { dir }, t}^{z, \text { prof }}= & \lambda \cdot \beta_{9} \cdot \sum_{g} \tau^{c} \cdot w_{t+g-9} \cdot A_{g, t+g-9}^{z, \text { prof }} \cdot \prod_{s=t+g-9}^{t}\left(1+g_{g d p_{s}}\right) \\
& +(1-\lambda) \cdot \text { Pens }_{8, t-1}^{z, p r o f}
\end{aligned}
$$

- Pro-rata method (2015 $\leq t \leq 2030)$ : with regard to the fraction $\lambda$ of individuals who retire between 60 and 64, pension benefits are given by a weighted average between the pension benefits computed with the earning based method and the contribution based method, whereas the fraction $(1-\lambda)$ of workers who retire in the previous period, receives $\operatorname{Pens} s_{8, d i r, t-1}^{z, p r o f}$.

Concerning the indexation of pension benefits, from 1992 onwards, pension benefits are not indexed to real wages, but to prices, and therefore remain constant over time in real terms:

$$
\text { Pens } s_{g, d i r, t+g-9}^{z, p r o f}=\text { Pens } s_{9, \text { dir }, t}^{z, \text { prof }}
$$

with $10 \leq g \leq 15$.

The transformation coefficients $\beta$ are defined by Law 335/1995 and vary according to the retirement age of the individual: they lie between $4.72 \%$ for people who retire at 57 and $6.136 \%$ for people who retire at 65 . According to Law 335/1995, these coefficients must be updated every 10 years according to the evolution of the life expectancy. In the model, the transformation coefficients used in the model for the age groups 55-59 and 60-64 (respectively $\beta_{8}$ and $\beta_{9}$ ) are endogenously determined by considering the average retirement age within the two age groups.

Concerning disability benefits and pension benefits to survivors we assume that they are proportional to the direct pension benefits. Disability benefits and pension benefits to survivors are then computed in the model by applying a coefficient that permits 
to reproduce the data concerning the average pension benefits (see below Tables 2 and 3 in Paragraph 4.1).

\subsubsection{Intertemporal budget constraint}

Each agent maximizes his/her intertemporal utility function conditional on his/her intertemporal budget constraint. For people who live until the last age group (95 years old), the end of life wealth is left as voluntary bequests. In the case of premature death, in order to avoid the presence of involuntary bequests, we assume the existence of a life insurance sector which offers actuarially fair annuities, where the actuarial rate of interest exceeds the market rate of interest by the conditional mortality probability (Yaari, 1965).

The present value of the final wealth is given by the difference between the present value of future incomes and the present value of future consumption. In particular, incomes are given by net labor incomes, net pensions and inheritances.

Thus, for each period, the budget constraint for an individual of origin $z$ and belonging to the age group $g$ is as follows:

$$
\begin{aligned}
\text { wealth }_{g+1, t+1}^{z}= & {\left[1+\left(1-\tau_{t}\right) \cdot r_{t}\right] \cdot \text { wealth }_{g, t}^{z}+} \\
& \left(1-\tau_{t}-\tau^{c}\right) \cdot w_{t} \cdot A_{g, t}^{z} \cdot l_{g, t}^{z}+ \\
& \sum_{\text {prof type }} \sum_{t}\left(1-\tau_{t}\right) \cdot \text { Pens }_{g, \text { type }, t}^{z, \text { typens }} \text { prof }_{g, t y p e, t}+ \\
& \left(1-\omega_{g, t}\right) \cdot \text { wealth }_{g+1, t+1}^{z} \\
& +i n h_{g}^{z} \cdot \text { beq }_{15, t}^{z} \cdot \frac{\operatorname{Pop}_{15, t}^{z}}{\text { Pop g, }_{g, t}^{z}} \\
& -c_{g, t}^{z}
\end{aligned}
$$

where: wealth $h_{g, t}^{z}$ is the wealth owned by individuals of origin $z$ and belonging to the age group $g ; r_{t}$ is the interest rate; $\tau_{t}$ is the income tax rate; $\tau^{c}$ is the social contribution rate (computed as the average between the social contribution rate applied to salaried workers and to self-employed workers); npens $s_{g, t y p e, t}^{\text {prof }}$ is the fraction of individuals belonging to the age group $g$ who receive pension benefits, according to the professional status and the type of benefits; ${ }^{13} \omega_{g, t}$ is the survival probability for an individual belonging to the class age $g$ in $t ; i n h_{g}^{z}$ is a parameter computed in order to distribute the voluntary bequests uniformly among the generations.

\footnotetext{
${ }^{13}$ The parameter $n$ pens $s_{g, \text { prof,type,t }}$ is related to $l_{g, t}^{z}$. In fact $l_{g, t}^{z}$ represents not only the fraction of time devoted to working by the representative agent, but can also be interpreted as the fraction of individuals that belong to an age class who work.
} 


\subsubsection{Optimal individual choices}

By maximizing utility, each individual chooses simultaneously the fraction of time to devote to schooling, his/her intertemporal profile of leisure and consumption, and the amount of bequest to leave if he/she survives until 95 years old.

The first order conditions are the following:

i) Decision of studying, which only concerns natives $(z=n a t)$ belonging to the age group $g=1$ :

$$
\begin{aligned}
& \left(1-\tau_{t}-\tau^{c}\right) \cdot \frac{w_{t} \cdot A_{1, t}^{n a t}}{\Delta} \\
= & \sum_{g=1}^{9} R_{t+g-1} \cdot\left(1-\tau_{t+g-1}-\tau^{c}\right) \cdot \\
& w_{t+g-1} \cdot l_{g, t+g-1}^{\text {nat }} \cdot \frac{\partial A_{g, t+g-1}^{\text {nat }}}{\partial\left[\Delta \cdot\left(1-l_{1, t}^{\text {nat }}\right)\right]} \cdot \Omega_{g, t+g-1}
\end{aligned}
$$

where $\tau_{t}$ is the income tax rate, $\tau^{c}$ is the social contribution rate (computed as the average between the social contribution rate applied to salaried workers and to selfemployed workers), $w_{t}$ is the wage rate and $R_{t}$ represents the discount factor, with $R_{t+g-1}=\prod_{s=t+1}^{t+g-1}\left(\frac{1}{1+\left(1-\tau_{t}\right) \cdot r_{t}}\right)$ where $r_{t}$ is the interest rate.

This condition means that if an individual decides at $t$ to study one more year, ${ }^{14}$ he gives up to one year of wage (the LHS) that, at the optimum, must be equal to the expected present value of all additional incomes earned thanks to the increase in the productivity related to human capital (the RHS).

Ceteris paribus, individuals decide to devote more time to human capital accumulation when future wages are expected to increase or future interest rates are expected to decrease, and when the survival probabilities increase.

ii) Decision concerning the leisure (for age groups $2 \leq g \leq 7$ ):

$$
1-l_{g, t}^{z}=\frac{\beta_{L_{g}}^{z}}{1-\beta_{L_{g}}^{z}} \cdot \frac{c_{g, t}^{z}}{\left(1-\tau_{t}-\tau^{c}\right) \cdot w_{t} \cdot A_{g, t}^{z}}
$$

Ceteris paribus, an increase in the net wage induces an increase in the individual's labor supply.

\footnotetext{
${ }^{14}$ Note that $\Delta \cdot\left(1-l_{1, t}^{\text {nat }}\right)$ indicates the number of years devoted to studying by people belonging to the first age group.
} 
iii) Intertemporal profile of consumption:

$$
\begin{aligned}
\frac{c_{g+1, t+1}^{z}}{c_{g, t}^{z}}= & {\left[\frac{1+\left(1-\tau_{t+1}\right) \cdot r_{t+1}}{1+\rho_{g+1}}\right]^{\gamma} \cdot\left(\frac{1-\beta_{L_{g+1}}^{z}}{1-\beta_{L_{g}}^{z}}\right)^{\gamma} \cdot\left[\frac{\left(\frac{\beta_{L_{g}}^{z}}{1-\beta_{L_{g}}^{z}}\right)^{\beta_{L_{g}}^{z}}}{\left(\frac{\beta_{L_{g+1}}^{z}}{1-\beta_{L_{g+1}}^{z}}\right)^{\beta_{L_{g+1}}^{z}}}\right]^{1-\gamma} . } \\
& {\left[\frac{\left[\left(1-\tau_{t+1}-\tau^{c}\right) \cdot A_{g+1, t+1}^{z} \cdot w_{t+1}\right]^{\beta_{L_{g+1}}^{z}}}{\left[\left(1-\tau_{t}-\tau^{c}\right) \cdot A_{g, t} \cdot w_{t}\right]^{\beta_{L_{g}}^{z}}}\right]^{1-\gamma} }
\end{aligned}
$$

iv) Voluntary bequests (for the age group $g=15$ ):

$$
b e q_{15, t+14}^{z}=\frac{\beta_{B_{15}}^{z}}{1-\beta_{B_{15}}^{z}} \cdot c_{15, t+14}^{z}
$$

The individual's optimal bequests are then proportional to his/her consumption in the last period of life.

\subsection{The government}

\subsubsection{The pension system}

The Italian pension system is a Pay-As-You-Go system in which workers pay social security contributions (33\% of wages for the public and private salaried workers and $20 \%$ of wages for self-employed workers) and the pension benefits are computed according to the rules introduced by the reforms Amato and Dini as described in Paragraph 3.3.3.

The deficit of the pension system is computed as follows:

$$
\begin{aligned}
\operatorname{Def}_{P S_{t}}= & \sum_{z} \sum_{g} \sum_{\text {prof }} \sum_{\text {type }} \operatorname{Pop}_{g, t}^{z} \cdot\left(1-\tau_{t}\right) \cdot \text { Pens }_{g, \text { type }, t}^{z, \text { prof }} \cdot \text { npens } \\
& \sum_{z} \sum_{g} \operatorname{Pop}_{g, t}^{z} \cdot \tau^{c} \cdot w_{t} \cdot A_{g, t}^{z} \cdot l_{g, t}^{z}-
\end{aligned}
$$

\subsubsection{Public expenditures and government savings}

In the model, we consider three types of public expenditures: expenditures on the education of young people aged from 5 to 24 , health care expenditures, and others public expenditures (public defence, public administration...). 
Public spending on education $\left(G e d u_{t}\right)$ is assumed to be proportional to the number of people attending school, while health care expenditure $\left(G m e d_{t}\right)$ is proportional to the number of people aged more than 60 .

We also assume that the average expenditure per student and the average health expenditure per old person vary over time according to the evolution of the GDP.

Concerning the other public expenditures $\left(G_{t}\right)$, we assume they grow at the same rate as the GDP.

Government savings $\left(S_{\text {govt }}\right.$ ) are given by the difference between revenues (taxes on labor and capital incomes and on pension benefits) and expenditures (on education, on health and public expenditures, the deficit of the pension system, and the interests paid on the public debt):

$$
\begin{aligned}
& S_{\text {gov } t}=\sum_{z} \sum_{g} \operatorname{Pop}_{g, t}^{z} \cdot \tau_{t} \cdot\left(w_{t} \cdot A_{g, t}^{z} \cdot l_{g, t}^{z}+r_{t} \cdot \text { wealth }_{g, t}^{z}\right) \\
& +\sum_{z} \sum_{g} \operatorname{Pop}_{g, t}^{z} \cdot \tau_{t} \cdot \sum_{\text {prof }} \sum_{\text {type }} \text { Pens }_{g, \text { type }, t}^{z, \text { rof }} \cdot \text { npens } s_{g, t y p e, t}^{\text {prof }} \\
& -\left(G_{e d u_{t}}+\text { Gmed }_{t}+G_{t}+\operatorname{Def}_{P S_{t}}+r_{t} \cdot B_{t}\right)
\end{aligned}
$$

We fix the ratio of the national debt $\left(B_{t}\right)$ to GDP and we determine, for each period, the income tax rate $\left(\tau_{t}\right)$ that permits to respect this budget constraint.

\subsection{Equilibrium conditions}

There are three markets in the model: the market of goods and services, the capital market and the labor market. These markets are supposed to be perfectly competitive, so prices adjust in order to guarantee the market clearing. The equilibrium conditions are the following:

$$
\begin{aligned}
Y_{t} & =\sum_{z} \sum_{g} \text { Pop }_{g, t}^{z} \cdot c_{g, t}^{z}+\text { Gedu }_{t}+\text { Gmed }_{t}+G_{t}+I_{t} \\
K_{t}+B_{t} & =\sum_{z} \sum_{g} \text { Pop }_{g, t}^{z} \cdot \text { wealth }_{g, t}^{z} \\
L_{t} & =\sum_{z} \sum_{g} \text { Pop }_{g, t}^{z} \cdot l_{g, t}^{z} \cdot A_{g, t}^{z}
\end{aligned}
$$

Equation (22) represents the equilibrium in the market of goods and services: production must be equal to aggregate demand, given by the private and public consumption and by the investments.

Equation (23) represents the equilibrium in the capital market. In our model we consider two assets, physical capital and government bonds, that are supposed perfectly 
substitutes, so their remuneration must be the same. The equilibrium condition is that assets demanded by firms and government (LHS) should equal the aggregate household wealth, where the individual wealth wealt $h_{g, t}^{z}$ is defined in Equation (15). Equation (24) indicates that the total labor supply expressed in per unit of effective labor (RHS) is entirely used in the production activity.

One of previous equations is redundant by the Walras' Law and we consider the domestic good as the numeraire.

\subsection{Dynamics of the economy}

The dynamics of the economy concern the evolution of labor supply, capital, government bonds and productivity. The evolution of labor supply depends on the individual labor choices (i.e. the choices concerning the fraction of time devoted to schooling and leisure) and on the demographic evolution (i.e. the evolution of fertility rates, survival probabilities and immigration flows). The labor productivity evolves over time according to the endogenous growth mechanism described in Equation (6). Finally, the evolution of the capital stock depends on investments and on capital depreciation, while public debt depends on government savings, as follows:

$$
\begin{aligned}
K_{t+1} & =K_{t} \cdot(1-\delta)+I_{t} \\
B_{t+1} & =B_{t}-S_{\text {gov }_{t}}
\end{aligned}
$$

\section{Calibration of the model}

The aim of our calibration is two-fold: reproduce the 2005 Italian macroeconomic data (in particular, the value of the GDP, the ratio between aggregate consumption and GDP, the ratio between investments and GDP, and the ratio between public expenditures and GDP) and replicate the most important ingredients of the pension system (the ratio of the number of retirees to the number of workers, the average pension benefits for each type of pensions, and the ratio of the total pension expenditure to GDP).

\subsection{The calibration of the pension system}

Given that our objective is to evaluate the impacts of pension reforms in the context of population ageing, we focus on the IVS pensions (including old-age direct pensions, pensions to survivors and disability benefits). IVS pensions account for $13.64 \%$ of GDP in 2005 (Istat, 2007).

However, in our analysis, we do not consider: 
- IVS pensions paid by private institutions that account for $0.16 \%$ of GDP;

- Supplementary pensions ${ }^{15}$ that account for $0.33 \%$ of GDP;

- Pensions paid to people aged less than 55.

Then, the pension system analyzed in our paper accounts for $12.89 \%$ of GDP. In particular, pensions to public and private salaried workers account for $10.50 \%$ of GDP, while pensions to self-employed account for $2.39 \%$. Direct pensions account for $9.87 \%$ of GDP, disability benefits for $0.88 \%$ and pensions to survivors for $2.14 \%$. Tables 2 and 3 present the main characteristics of the pension system analyzed in our paper. Data show that, concerning direct pensions, the average pension benefits earned by self-employed are $40 \%$ lower than those earned by salaried workers. This relevant difference is not related to a different calculation rule of pensions: in fact, in 2005 , the gross replacement ratio was very similar for salaried workers and selfemployed. ${ }^{16}$ The difference in the average pension benefits is then related to an important difference in remuneration between salaried workers and self-employed workers, represented in our model by the coefficient $\Psi^{\text {prof }}$ in Equation (7).

Table 2: Pensions paid to the employees. Source: Istat, 2007

\begin{tabular}{|c|c|c|c|c|c|c|c|c|c|}
\hline & \multicolumn{3}{|c|}{ Direct Pensions } & \multicolumn{3}{|c|}{ Disability Pensions } & \multicolumn{3}{|c|}{ Indirect Pensions } \\
\hline & N. of pensions & $\begin{array}{l}\text { Expenditure } \\
\text { (000 euros) }\end{array}$ & $\begin{array}{l}\text { Average } \\
\text { pension }\end{array}$ & N. of pensions & $\begin{array}{c}\text { Expenditure } \\
\text { (000 euros) }\end{array}$ & $\begin{array}{l}\text { Average } \\
\text { pension }\end{array}$ & N. of pensions & $\begin{array}{l}\text { Expenditure } \\
\text { (000 euros) }\end{array}$ & $\begin{array}{l}\text { Average } \\
\text { pension }\end{array}$ \\
\hline $55-59$ & 790716 & 15507566 & 19612 & 90062 & 824026 & 9150 & 155738 & 1239611 & 7960 \\
\hline $60-64$ & 1274702 & 21885456 & 17169 & 91203 & 754850 & 8277 & 213237 & 1743589 & 8177 \\
\hline $65-69$ & 1687695 & 25292352 & 14986 & 111556 & 831191 & 7451 & 376179 & 3040756 & 8083 \\
\hline $70-74$ & 1533347 & 20186641 & 13165 & 171320 & 1221380 & 7129 & 549334 & 4318436 & 7861 \\
\hline 75-79 & 1246960 & 15635855 & 12539 & 261016 & 1824525 & 6990 & 715720 & 5502937 & 7689 \\
\hline $80-84$ & 854241 & 10177760 & 11914 & 278749 & 1865127 & 6691 & 727666 & 5460919 & 7505 \\
\hline $85-89$ & 326457 & 3691577 & 11308 & 136930 & 875907 & 6397 & 378442 & 2796284 & 7389 \\
\hline$>90$ & 202327 & 2092297 & 10341 & 88636 & 538449 & 6075 & 296497 & 2150206 & 7252 \\
\hline Total & 7916445 & 114469504 & 14460 & 1229472 & 8735454 & 7105 & 3412813 & 26252738 & 7692 \\
\hline
\end{tabular}

\footnotetext{
${ }^{15}$ Supplementary pension systems, recently introduced in the Italian system, are mostly funded and voluntary. They include closed-end funds and collective pension funds.

${ }^{16}$ In 2005, according to Ragioneria Generale dello Stato (2006), in the case of an individual aged 63 with 35 years of contributions, the gross replacement ratio was $70.7 \%$ for the employees and $69 \%$ for the self-employed. In the case of an individual with 40 years of contributions, the gross replacement ratio was $80.7 \%$ for the employees and $78.7 \%$ for the self-employed.
} 
A General Equilibrium Evaluation of the New Pension Reforms in Italy

Table 3: Pensions paid to self-employed. Source: Istat, 2007

\begin{tabular}{|c|c|c|c|c|c|c|c|c|c|}
\hline & \multicolumn{3}{|c|}{ Direct Pensions } & \multicolumn{3}{|c|}{ Disability Pensions } & \multicolumn{3}{|c|}{ Indirect Pensions } \\
\hline & N. of pensions & $\begin{array}{c}\text { Expenditure } \\
(000 \text { euros) }\end{array}$ & $\begin{array}{l}\text { Average } \\
\text { pension }\end{array}$ & N. of pensions & $\begin{array}{c}\text { Expenditure } \\
\text { (000 euros) }\end{array}$ & $\begin{array}{l}\text { Average } \\
\text { pension }\end{array}$ & N. of pensions & $\begin{array}{l}\text { Expenditure } \\
(000 \text { euros) }\end{array}$ & $\begin{array}{r}\text { Average } \\
\text { pension }\end{array}$ \\
\hline $55-59$ & 178373 & 2200736 & 12338 & 41572 & 305540 & 7350 & 58627 & 322835 & 5507 \\
\hline $60-64$ & 675952 & 6538672 & 9673 & 39154 & 263017 & 6718 & 81210 & 437748 & 5390 \\
\hline $65-69$ & 862610 & 7610403 & 8823 & 43497 & 257300 & 5915 & 125291 & 645156 & 5149 \\
\hline $70-74$ & 612617 & 4711729 & 7691 & 68782 & 386936 & 5626 & 150438 & 715833 & 4758 \\
\hline 75-79 & 417259 & 2882303 & 6908 & 120743 & 651327 & 5394 & 176310 & 762964 & 4327 \\
\hline $80-84$ & 224383 & 1443424 & 6433 & 166721 & 880195 & 5279 & 181448 & 714331 & 3937 \\
\hline $85-89$ & 65558 & 389712 & 5945 & 105712 & 552372 & 5225 & 99543 & 361353 & 3630 \\
\hline$>90$ & 41348 & 228313 & 5522 & 90814 & 469756 & 5173 & 90442 & 302753 & 3347 \\
\hline Total & 3078100 & 26005293 & 8448 & 676995 & 3766444 & 5563 & 963309 & 4262972 & 4425 \\
\hline
\end{tabular}

\subsection{The calibration of the macroeconomy}

The model is calibrated conditional to the demographic change, to an endogenous annual productivity growth rate of about $1.5 \%$, and to the pension reforms introduced in the Nineties. In particular, the demographic shock is introduced through a combination of changes in fertility rates, mortality rates and immigration flows, determined to reproduce as closely as possible demographic projections presented by Istat as described in Paragraph 3.2.

Our model starts in 1950. The calibration is done in a way we reproduce the 2005 observed data. ${ }^{17}$ In Table 4 we report the main values of the parameters used in the model, whereas in Tables 5, 6 and 7 we report the values for some endogenous variables produced by the model that we compare to the 2005 data.

In particular, the parameter that measures the intensity of the preference for bequests $\left(\beta_{B}^{z}\right)$ and the intertemporal preference factor $\left(\Gamma_{g}\right)$ used in the utility function (Equation (2)) are calibrated to reproduce a wealth profile of the different age groups compatible with the 2005 data. ${ }^{18}$ The parameters that measure the intensity of the preference for leisure $\left(\beta_{L_{g}}^{z}\right)$ in Equation (2) are calibrated to replicate the employment rates of the different age groups in 2005. These parameters are allowed to change over time in order to take into account the increase in women labor participation in the next decades that mainly depends on cultural factors.

Concerning the individual productivity, the parameters $\theta_{0}, \theta_{1}$ and $\theta_{2}$ in Equation (3) are calibrated to replicate the earnings profile used by Fougère and Mérette (1999) that were set to produce a maximum at the age of 52. The parameter $\alpha_{H C}$ in Equation (4) is calibrated to replicate in 2005 the fraction of young people (20-24 years old)

\footnotetext{
${ }^{17}$ In other words, we determine the stocks in 1950 and the intertemporal prices between 1950 and 2005 in order to reproduce the 2005 real data.

${ }^{18}$ Most of the OLG models consider an intertemporal preference rate identical for each age groups and no bequest motive, as in Miles (1999). Therefore, in this case, old people present a very negative value of the propensity to save, that is not consistent to real data.
} 
who study. The parameter $\chi$ in Equation (6) is calibrated to obtain a productivity growth rate in 2005 close to $1.5 \%$. The parameter $\theta^{z}$ is chosen such that the total productivity of immigrants is lower by $13 \%$ of the total productivity of natives. ${ }^{19}$

Both the calibration and simulations were made by using numerical algorithms provided by GAMS (General Algebraic Modelling System).

Table 4: Some parameters used in the model

\begin{tabular}{lll}
\hline Households & & \\
\hline & $\theta_{0}$ & 0.675 \\
Productivity related to the age & $\theta_{1}$ & 0.350 \\
& $\theta_{2}$ & -0.025 \\
\hline Productivity related to the education & $\alpha_{H C}$ & 0.339 \\
Productivity related to the average level of knowledge & $\chi$ & 0.089 \\
Intertemporal elasticity of substitution & $\gamma$ & 0.75 \\
\hline & $\beta_{L_{2}}$ & 0.597 \\
& $\beta_{L_{3}}$ & 0.713 \\
Index of preference for leisure & $\beta_{L_{4}}$ & 0.744 \\
& $\beta_{L_{5}}$ & 0.754 \\
& $\beta_{L_{6}}$ & 0.761 \\
& $\beta_{L_{7}}$ & 0.735 \\
\hline Index of preference for bequests & $\beta_{B}$ & 1.098 \\
& & \\
\hline Firms & & \\
\hline Annual depreciation rate of physical capital & $\delta$ & $5 \%$ \\
Capital remuneration in the added value & $\alpha$ & 0.412 \\
\hline Government & & \\
\hline Contribution rate applied to salaried workers & & \\
Contribution rate applied to self-employed workers & & $20 \%$ \\
Average contribution rate & $\tau^{c}$ & $23.3 \%$ \\
\hline Public debt / GDP & & $106.4 \%$ \\
\hline & & $20.4 \%$ \\
\hline
\end{tabular}

\footnotetext{
${ }^{19}$ Storesletten (2000) finds, for the United States, that the productivity of people who immigrate at 37 years old is lower by $13 \%$ with respect to that of natives. In our case, this assumption implies that immigrants have a level of productivity related to education lower by $13 \%$ compared to natives. In fact, we can suppose that an immigrant and a native, with the same age, have the same productivity related to the experience $(E P)$ and that they profit in the same way of the knowledge present in the economy $(H)$. By considering Equation (4), this assumption implies that immigrants have a stock of human capital lower by $10 \%$ relatively to natives.
} 
A General Equilibrium Evaluation of the New Pension Reforms in Italy

Table 5: Variables concerning the macroeconomy, year 2005

\begin{tabular}{lcc}
\hline & Simulated value & Real data \\
\hline GDP (in milliards of euros) & 1423.022 & 1423.049 \\
Consumption / GDP & $59.00 \%$ & $58.63 \%$ \\
Investments / GDP & $20.50 \%$ & $20.42 \%$ \\
Gedu / GDP & $4.58 \%$ & $4.62 \%$ \\
Gmed / GDP & $6.95 \%$ & $6.93 \%$ \\
G / GDP & $8.96 \%$ & $8.87 \%$ \\
Income tax rate & $14.8 \%$ & \\
K / GDP & 2.65 & \\
\hline
\end{tabular}

Table 6: Variables concerning the labor market, year 2005

\begin{tabular}{lccc}
\hline & & Simulated value & Real data \\
\hline & $20-24$ & $41.16 \%$ & $41.11 \%$ \\
& $25-29$ & $63.24 \%$ & $63.26 \%$ \\
Employment rates & $30-34$ & $74.06 \%$ & $74.36 \%$ \\
& $35-39$ & $76.01 \%$ & $76.22 \%$ \\
& $45-44$ & $76.23 \%$ & $76.40 \%$ \\
& $50-54$ & $74.03 \%$ & $74.06 \%$ \\
\hline National employment rate & $66.71 \%$ & $66.87 \%$ \\
Employment rate for natives & $43.07 \%$ & $43.07 \%$ \\
Employment rate for immigrants & 65.59 & $69.85 \%$ & $17.99 \%$ \\
\hline \multicolumn{2}{l}{ Retirees / Workers } & & $61.48 \%$ \\
\hline
\end{tabular}

Table 7: Pension system expenditures with respect to GDP, year 2005

\begin{tabular}{llcc}
\hline & & Simulated value & Real data \\
\hline All pensions & & $12.97 \%$ & $12.89 \%$ \\
\hline \multirow{2}{*}{ Salaried workers } & direct pensions & $8.09 \%$ & $8.04 \%$ \\
& disability benefits & $0.61 \%$ & $0.61 \%$ \\
& indirect pensions & $1.82 \%$ & $1.84 \%$ \\
\hline \multirow{2}{*}{ Self-employed workers } & direct pensions & $1.89 \%$ & $1.83 \%$ \\
& disability benefits & $0.26 \%$ & $0.26 \%$ \\
& indirect pensions & $0.30 \%$ & $0.30 \%$ \\
\hline
\end{tabular}




\section{EfFects of the ReCent Reforms: Berlusconi ANd Prodi REFORMS}

We now use the model to simulate and compare the pension reforms recently introduced: the Berlusconi reform (2004) and the Prodi reform (2007). Whereas with the Dini reform workers can decide to retire between 57 and 65, the two new reforms increase the minimum retirement age, as described in Table 1 in Paragraph 2. These two reforms are compared with our base scenario in which the increase in the retirement age is not taken into account.

\subsection{Macroeconomic impacts}

First of all, the increase in the retirement age will have a direct impact on the labor supply. Figures 9 and 10 show that, with respect to the base case, the increase in the retirement age induces an increase in the employment rate, i.e. the ratio between the number of workers and the working age population (20-64), and a reduction in the ratio of the number of retirees to the number of workers. ${ }^{20}$

In the three cases, the population ageing phenomenon boosts the capital per unit of effective labor that raises the equilibrium per unit of effective wage and reduces the equilibrium (net of tax) interest rate (Figures 11 and 12). The fact that the two reforms induce an increase in the labor supply explains why wages are lower and the interest rate is higher with respect to the base case.

The increase of survival probabilities and future wages and the decrease of future interest rates affect positively the optimal time devoted to studying by young people (Figure 13). Moreover, with respect to the base scenario, the increase in the retirement age and then in the overall lifetime spent working, induce young people to devote additional time to human capital accumulation. The productivity growth rate, that depends on the weighted average of the productivity levels of each age group, increases over time (Figure 14): from $1.5 \%$ in 2005 to $1.7 \%$ in 2055. However, a more important investment in human capital, with respect to the base case, is not sufficient to induce a greater pace of the productivity growth rate. This is related to the fact that the two reforms induce an increase of the weight of people aged 55-64 (with a lower human capital stock given the hypothesis of the depreciation of human capital) which reduces the average level of human capital.

\footnotetext{
${ }^{20}$ Note that, from an economic point of view, the ratio of the retirees to the workers speaks more than the old-age dependency ratio, since it also takes into account the evolution of the employment ratio.
} 
Figure 9: Employment rate

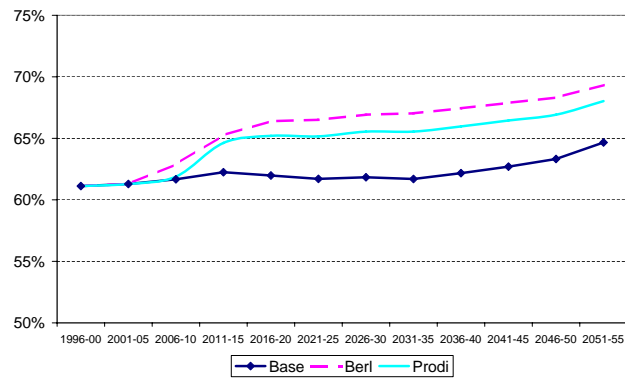

Figure 11: Wage, per unit of effective labor

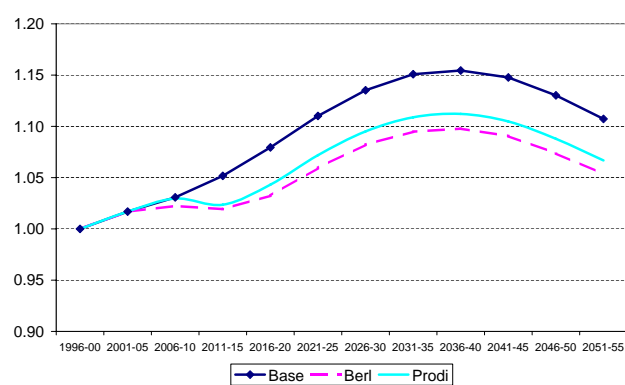

Figure 13: Time devoted to schooling

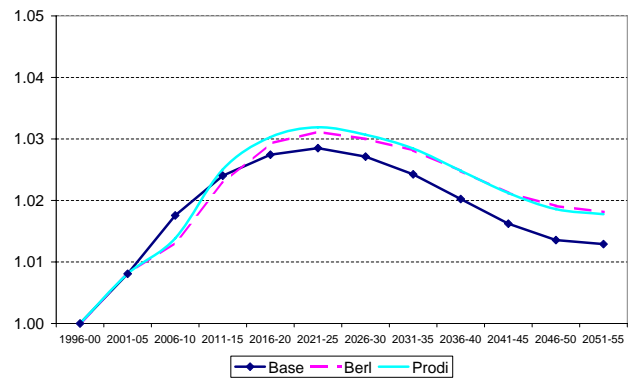

Figure 10: \# retirees / \# workers

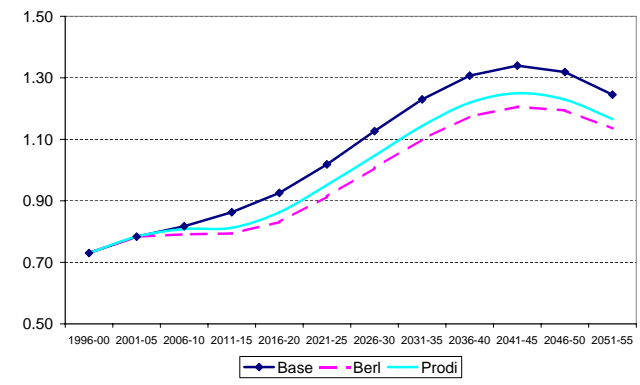

Figure 12: Interest rate

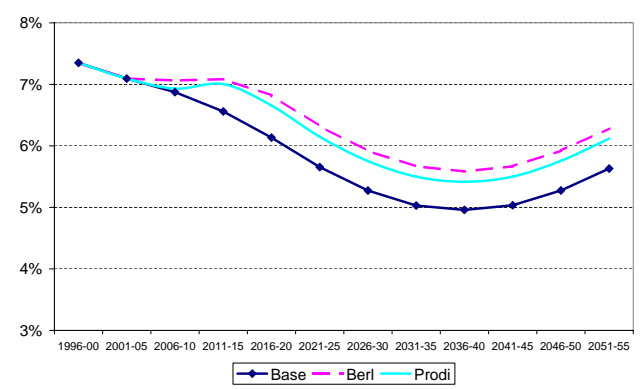

Figure 14: Productivity growth rate

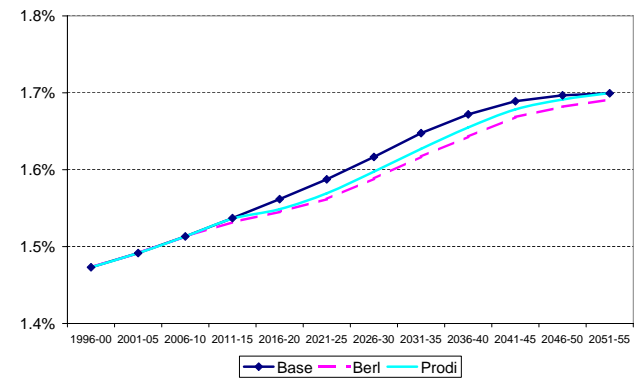

The macroeconomic effects, in terms of economic growth, of the increase in retirement age are positive until 2025. Starting from 2025, the difference with respect to 
the base scenario becomes insignificant.

In the base scenario, the ratio of investments to GDP (Figure 15) increases until 2020 and then it drastically decreases. The initial increase is related to the Dini reform that will significantly reduce pension benefits with the application of the contribution based method, and to the Amato reform that introduced an indexation mechanism of pension benefits to prices. It is well known that a reduction in the generosity of the pension system stimulates national savings by modifying the individual behavior in terms of consumption and saving. However, after some periods, investments over GDP decrease because the positive effect on private savings is more than compensated by the high deficits generated by the pension system.

With respect to the base scenario, the increase in the retirement age has a negative impact on the ratio of investments to GDP. With the reform, in fact, individuals expect to work more and earn more in the future (both in terms of labor incomes and pension benefits) so they can increase their consumption levels and reduce their actual savings. ${ }^{21}$

The evolution of GDP is mainly affected by the demographic projections. The strong reduction in the population aged between 20 and 64 implies negative rates of growth of the number of workers from 2015 to 2055 (Figure 16) and explains the negative evolution GDP growth (Figure 17) and per capita GDP growth (Figure 18). The evolution of the investment ratio plays another negative role in the economic growth, while the increase in the productivity growth rate and the increase in the employment rates are not sufficient to compensate the previous negative effects.

With respect to the base scenario, the reforms would induce an increase in the growth rate of the number of workers and consequently of the GDP growth rate and per capita GDP growth rate until 2025. Afterwards, the economic growth rates are very similar in the three scenarios.

\footnotetext{
${ }^{21}$ The closed-economy assumption is the key to this result. As argued in the introduction, although Italy is clearly an open economy, the simultaneity of pension reforms around the world yields a fall in investments.
} 
Figure 15: Investments / GDP

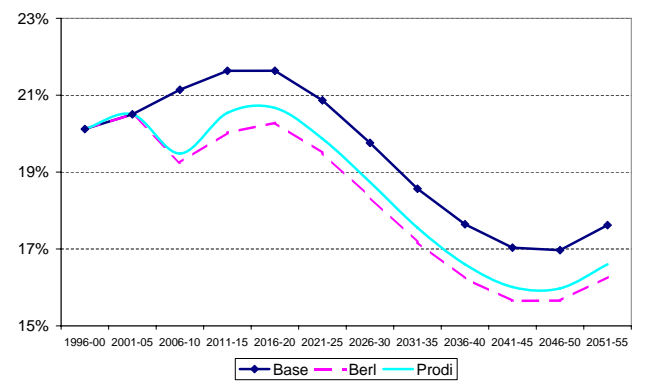

Figure 17: GDP growth rate

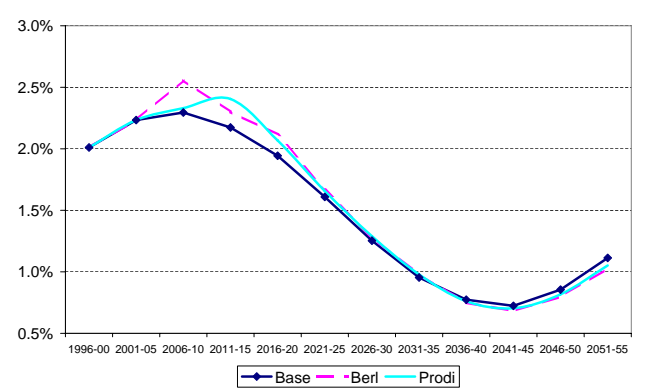

Figure 16: Growth rate of the \# of workers

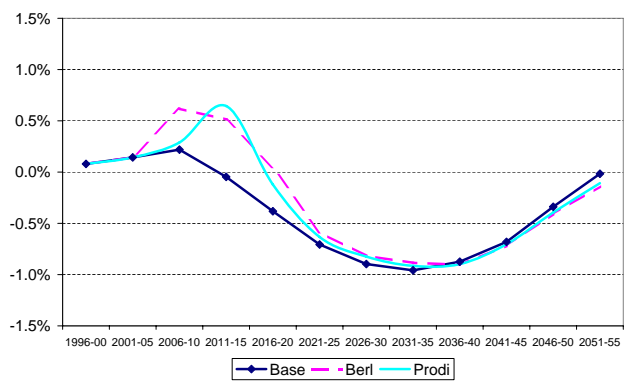

Figure 18: Per capita GDP growth rate

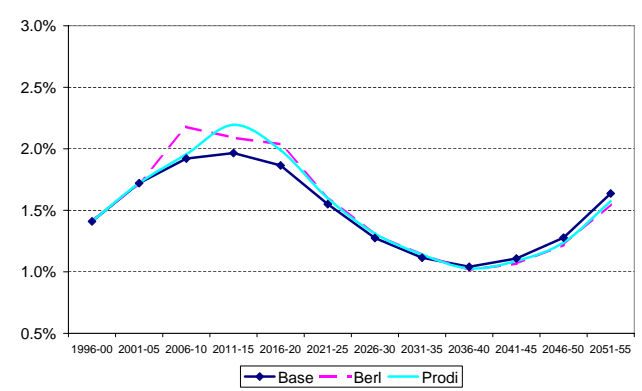

\subsection{Effects of the Berlusconi and Prodi reforms on the pension system}

Figures 19 and 20 show the evolution of the pension system in terms of expenditures and deficits produced. We see that initially the two reforms that increase the retirement age have a significant positive impact on the financial situation of the pension system with respect to the base scenario, both in terms of the deficit and of the aggregate expenditure, as a ratio to GDP. For example, the Berlusconi reform makes it possible to reduce the ratio of the deficit to GDP of about 0.7 percentage points in 2015 and 0.3 p.p. in 2030. As could be expected, reduction in the pension deficits with the Prodi reform is less important in the short run than with the Berlusconi reform. The reduction is 0.5 p.p. in $2015,0.2$ p.p. in 2030 with respect to the base scenario.

However, in the long run, the increase in the retirement age becomes completely ineffective. In year 2035, the two reforms display the same ratio of the pension 
system deficit to GDP as in the base scenario, and afterwards, this ratio becomes more important than in the base case.

Figure 19: Pension system deficit / GDP

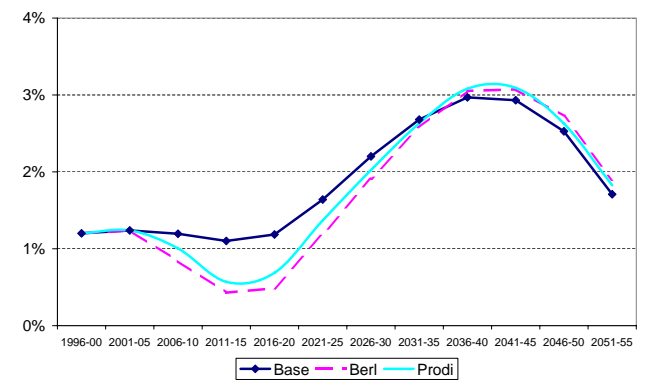

Figure 20: Pension expenditure / GDP

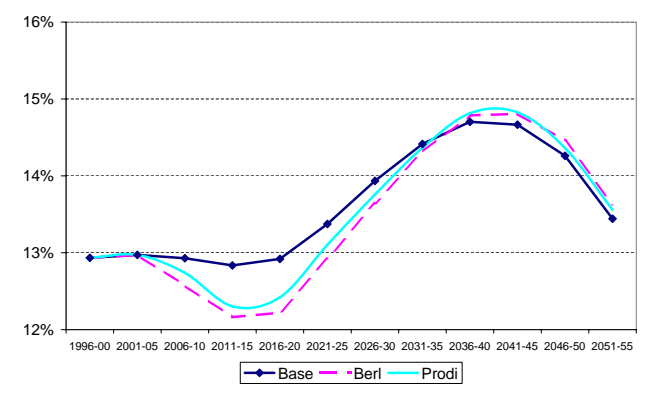

In order to understand the reason behind the inefficiency of these reforms in the long run, we have to consider that an increase in the retirement age induces a present loss (represented by the additional contributions paid and by the foregone pension benefits) and future gains (represented by the increase in the value of the pension thereafter). In the early years of the introduction of the reform, the increase in the retirement age can only have positive effects on the pension system. However, as time passes, a larger number of individuals receive the increase in pension benefits. To show this, let us imagine that before the reform each individual retires at 58 and that the reform increases the retirement age by one year from 2008 onwards. In 2008, people who are forced to postpone retirement pay one more year of contributions and loose one year of pension benefits. Their loss represents a net gain for the pension system since pension benefits do not change for any age groups that year. The next year, the pension system receives the same increase in contributions but this gain is now partially compensated by the increase in pension benefits paid to the retirees who, without the reform, would have retired at 58 in 2008 but, with the reform, retire at 59 in 2009. In 2010 two age groups benefit from the increase in pensions: people who, without the reform, would retire at 58 in 2008 and at 58 in 2009 but, with the reform, are constrained to work one additional year. And so on. So, as time passes by, the number of individuals who earns a greater level of pension benefits increases and the increase in the pension expenditure compensates the increase in the social contributions paid by the workers obliged to work more, and the reform ceases to be effective.

Another element that makes the reform ineffective in the long run is related to the contribution based method introduced by the Dini reform in order to penalize early 
retirement. In 2005, as Table 8 and 9 show respectively for salaried workers and self-employed workers, the rate of return on contributions ${ }^{22}$ for those who retire at 57 was largely higher than that of individuals who postpone retirement; in contrast, from 2040 onwards, the difference between the rates of return on contributions is significantly reduced. This implies that, when the earning based method is applied and the rate of return on contributions are different according the retirement age, if an individual works one more year the increase in the value of his/her pension is less important in the case where the rates of return on contributions are equal for all individuals. In contrast, with the contribution based method and the presence of an actuarial link between pension benefits and contributions paid, if an individual decides to work one more year, the increase in the value of his/her pension is more relevant. Thus, in every case, the increase in the retirement age causes an increase in pension benefits, but this increase is more important when the contribution based method is applied. The fact that starting from 2045 the majority of the retirees receive a pension computed with the contribution based method represents another element that influences negatively the evolution of pension system.

Table 8: Rate of return on contributions; native employees; base scenario.

Source: Author's calculations

\begin{tabular}{lccccccccc}
\hline Retirement age & 57 & 58 & 59 & 60 & 61 & 62 & 63 & 64 & 65 \\
Years of contributions & 35 & 36 & 37 & 38 & 39 & 40 & 41 & 42 & 43 \\
\hline $2001-05$ & $3.20 \%$ & $3.05 \%$ & $2.89 \%$ & $2.73 \%$ & $2.45 \%$ & $2.30 \%$ & $2.14 \%$ & $1.98 \%$ & $1.81 \%$ \\
$2006-10$ & $3.29 \%$ & $3.14 \%$ & $2.98 \%$ & $2.82 \%$ & $2.51 \%$ & $2.36 \%$ & $2.20 \%$ & $2.04 \%$ & $1.86 \%$ \\
$2011-15$ & $3.33 \%$ & $3.18 \%$ & $3.01 \%$ & $2.84 \%$ & $2.52 \%$ & $2.36 \%$ & $2.19 \%$ & $2.01 \%$ & $1.83 \%$ \\
$2016-20$ & $2.90 \%$ & $2.78 \%$ & $2.66 \%$ & $2.53 \%$ & $2.34 \%$ & $2.24 \%$ & $2.13 \%$ & $2.03 \%$ & $1.92 \%$ \\
$2021-25$ & $2.77 \%$ & $2.66 \%$ & $2.56 \%$ & $2.45 \%$ & $2.29 \%$ & $2.21 \%$ & $2.12 \%$ & $2.03 \%$ & $1.93 \%$ \\
$2026-30$ & $2.57 \%$ & $2.49 \%$ & $2.40 \%$ & $2.31 \%$ & $2.20 \%$ & $2.13 \%$ & $2.06 \%$ & $1.98 \%$ & $1.90 \%$ \\
$2031-35$ & $2.21 \%$ & $2.16 \%$ & $2.10 \%$ & $2.05 \%$ & $2.01 \%$ & $1.97 \%$ & $1.92 \%$ & $1.87 \%$ & $1.82 \%$ \\
$2036-40$ & $2.06 \%$ & $2.01 \%$ & $1.97 \%$ & $1.91 \%$ & $1.88 \%$ & $1.85 \%$ & $1.80 \%$ & $1.76 \%$ & $1.71 \%$ \\
$2041-45$ & $1.91 \%$ & $1.88 \%$ & $1.83 \%$ & $1.79 \%$ & $1.76 \%$ & $1.73 \%$ & $1.69 \%$ & $1.64 \%$ & $1.60 \%$ \\
$2046-50$ & $1.80 \%$ & $1.77 \%$ & $1.73 \%$ & $1.69 \%$ & $1.66 \%$ & $1.63 \%$ & $1.59 \%$ & $1.55 \%$ & $1.51 \%$ \\
$2051-55$ & $1.75 \%$ & $1.72 \%$ & $1.68 \%$ & $1.64 \%$ & $1.62 \%$ & $1.59 \%$ & $1.55 \%$ & $1.51 \%$ & $1.47 \%$ \\
\hline
\end{tabular}

\footnotetext{
${ }^{22}$ The rate of return on contributions is defined as the rate that equalizes the expected capitalized value of the contributions paid and the expected present value of the pension benefits earned. Note that if an individual decides (or is constrained by the law) to work one more year, and assuming that the rate of return on contributions does not depend on the age of retirement, the increase in pension benefits must be such that the expected present value of the future increase in pension benefits is equal to the sum of the additional contributions paid and the pension benefits given up.
} 
Table 9: Rate of return on contributions; native self-employed; base scenario.

Source: Author's calculations

\begin{tabular}{lccccccccc}
\hline Retirement age & 57 & 58 & 59 & 60 & 61 & 62 & 63 & 64 & 65 \\
Years of contributions & 35 & 36 & 37 & 38 & 39 & 40 & 41 & 42 & 43 \\
\hline $2001-05$ & $4.92 \%$ & $4.75 \%$ & $4.57 \%$ & $4.38 \%$ & $4.09 \%$ & $3.93 \%$ & $3.75 \%$ & $3.57 \%$ & $3.38 \%$ \\
$2006-10$ & $5.02 \%$ & $4.85 \%$ & $4.66 \%$ & $4.47 \%$ & $4.16 \%$ & $4.00 \%$ & $3.82 \%$ & $3.63 \%$ & $3.44 \%$ \\
$2011-15$ & $5.07 \%$ & $4.89 \%$ & $4.71 \%$ & $4.51 \%$ & $4.17 \%$ & $4.00 \%$ & $3.81 \%$ & $3.62 \%$ & $3.41 \%$ \\
$2016-20$ & $3.90 \%$ & $3.74 \%$ & $3.58 \%$ & $3.41 \%$ & $3.17 \%$ & $3.03 \%$ & $2.89 \%$ & $2.75 \%$ & $2.61 \%$ \\
$2021-25$ & $3.52 \%$ & $3.38 \%$ & $3.24 \%$ & $3.10 \%$ & $2.90 \%$ & $2.79 \%$ & $2.67 \%$ & $2.55 \%$ & $2.43 \%$ \\
$2026-30$ & $3.05 \%$ & $2.94 \%$ & $2.83 \%$ & $2.72 \%$ & $2.58 \%$ & $2.49 \%$ & $2.40 \%$ & $2.30 \%$ & $2.21 \%$ \\
$2031-35$ & $2.21 \%$ & $2.16 \%$ & $2.10 \%$ & $2.05 \%$ & $2.01 \%$ & $1.97 \%$ & $1.92 \%$ & $1.87 \%$ & $1.82 \%$ \\
$2036-40$ & $2.06 \%$ & $2.01 \%$ & $1.97 \%$ & $1.91 \%$ & $1.88 \%$ & $1.85 \%$ & $1.80 \%$ & $1.76 \%$ & $1.71 \%$ \\
$2041-45$ & $1.91 \%$ & $1.88 \%$ & $1.83 \%$ & $1.79 \%$ & $1.76 \%$ & $1.73 \%$ & $1.69 \%$ & $1.64 \%$ & $1.60 \%$ \\
$2046-50$ & $1.80 \%$ & $1.77 \%$ & $1.73 \%$ & $1.69 \%$ & $1.66 \%$ & $1.63 \%$ & $1.59 \%$ & $1.55 \%$ & $1.51 \%$ \\
$2051-55$ & $1.75 \%$ & $1.72 \%$ & $1.68 \%$ & $1.64 \%$ & $1.62 \%$ & $1.59 \%$ & $1.55 \%$ & $1.51 \%$ & $1.47 \%$ \\
\hline
\end{tabular}

Table 10: Gross replacement ratio; native employees; base scenario.

Source: Author's calculations

\begin{tabular}{lccccccccc}
\hline Retirement age & 57 & 58 & 59 & 60 & 61 & 62 & 63 & 64 & 65 \\
Years of contributions & 35 & 36 & 37 & 38 & 39 & 40 & 41 & 42 & 43 \\
\hline $2001-05$ & $70.3 \%$ & $72.7 \%$ & $75.0 \%$ & $77.4 \%$ & $77.8 \%$ & $80.0 \%$ & $82.3 \%$ & $84.5 \%$ & $86.8 \%$ \\
$2006-10$ & $70.1 \%$ & $72.5 \%$ & $74.9 \%$ & $77.3 \%$ & $77.5 \%$ & $79.8 \%$ & $82.2 \%$ & $84.5 \%$ & $86.9 \%$ \\
$2011-15$ & $70.2 \%$ & $72.7 \%$ & $75.2 \%$ & $77.6 \%$ & $77.7 \%$ & $80.0 \%$ & $82.4 \%$ & $84.8 \%$ & $87.3 \%$ \\
$2016-20$ & $62.8 \%$ & $65.6 \%$ & $68.6 \%$ & $71.7 \%$ & $74.5 \%$ & $78.1 \%$ & $81.9 \%$ & $86.0 \%$ & $90.4 \%$ \\
$2021-25$ & $59.8 \%$ & $62.8 \%$ & $65.9 \%$ & $69.3 \%$ & $72.7 \%$ & $76.5 \%$ & $80.7 \%$ & $85.1 \%$ & $89.9 \%$ \\
$2026-30$ & $56.1 \%$ & $59.2 \%$ & $62.4 \%$ & $65.9 \%$ & $70.0 \%$ & $74.0 \%$ & $78.4 \%$ & $83.0 \%$ & $88.1 \%$ \\
$2031-35$ & $51.9 \%$ & $55.3 \%$ & $58.8 \%$ & $62.6 \%$ & $67.8 \%$ & $72.3 \%$ & $77.0 \%$ & $82.1 \%$ & $87.7 \%$ \\
$2036-40$ & $48.9 \%$ & $52.1 \%$ & $55.4 \%$ & $59.0 \%$ & $65.7 \%$ & $70.1 \%$ & $74.7 \%$ & $79.7 \%$ & $85.1 \%$ \\
$2041-45$ & $47.6 \%$ & $50.7 \%$ & $54.0 \%$ & $57.6 \%$ & $62.6 \%$ & $66.8 \%$ & $71.2 \%$ & $75.9 \%$ & $81.1 \%$ \\
$2046-50$ & $46.7 \%$ & $49.8 \%$ & $53.1 \%$ & $56.6 \%$ & $61.6 \%$ & $65.6 \%$ & $70.0 \%$ & $74.6 \%$ & $79.7 \%$ \\
$2051-55$ & $46.7 \%$ & $49.8 \%$ & $53.1 \%$ & $56.6 \%$ & $61.3 \%$ & $65.4 \%$ & $69.7 \%$ & $74.3 \%$ & $79.3 \%$ \\
\hline
\end{tabular}


A General Equilibrium Evaluation of the New Pension Reforms in Italy

Table 11: Gross replacement ratio; native self-employed; base scenario.

Source: Author's calculations

\begin{tabular}{lccccccccc}
\hline Retirement age & 57 & 58 & 59 & 60 & 61 & 62 & 63 & 64 & 65 \\
Years of contributions & 35 & 36 & 37 & 38 & 39 & 40 & 41 & 42 & 43 \\
\hline $2001-05$ & $66.3 \%$ & $68.7 \%$ & $71.1 \%$ & $73.5 \%$ & $74.0 \%$ & $76.2 \%$ & $78.5 \%$ & $80.7 \%$ & $83.0 \%$ \\
$2006-10$ & $65.9 \%$ & $68.3 \%$ & $70.7 \%$ & $73.1 \%$ & $73.7 \%$ & $75.9 \%$ & $78.2 \%$ & $80.4 \%$ & $82.7 \%$ \\
$2011-15$ & $65.9 \%$ & $68.4 \%$ & $70.9 \%$ & $73.4 \%$ & $73.6 \%$ & $75.9 \%$ & $78.3 \%$ & $80.6 \%$ & $83.0 \%$ \\
$2016-20$ & $49.3 \%$ & $51.2 \%$ & $53.1 \%$ & $55.2 \%$ & $56.6 \%$ & $58.9 \%$ & $61.3 \%$ & $63.9 \%$ & $66.7 \%$ \\
$2021-25$ & $44.1 \%$ & $46.0 \%$ & $48.1 \%$ & $50.2 \%$ & $52.1 \%$ & $54.5 \%$ & $57.1 \%$ & $59.8 \%$ & $62.8 \%$ \\
$2026-30$ & $38.5 \%$ & $40.5 \%$ & $42.5 \%$ & $44.7 \%$ & $47.0 \%$ & $49.6 \%$ & $52.2 \%$ & $55.1 \%$ & $58.2 \%$ \\
$2031-35$ & $31.5 \%$ & $33.5 \%$ & $35.6 \%$ & $37.9 \%$ & $41.1 \%$ & $43.8 \%$ & $46.7 \%$ & $49.8 \%$ & $53.1 \%$ \\
$2036-40$ & $29.6 \%$ & $31.6 \%$ & $33.6 \%$ & $35.8 \%$ & $39.8 \%$ & $42.5 \%$ & $45.3 \%$ & $48.3 \%$ & $51.6 \%$ \\
$2041-45$ & $28.8 \%$ & $30.7 \%$ & $32.7 \%$ & $34.9 \%$ & $37.9 \%$ & $40.5 \%$ & $43.1 \%$ & $46.0 \%$ & $49.2 \%$ \\
$2046-50$ & $28.3 \%$ & $30.2 \%$ & $32.2 \%$ & $34.3 \%$ & $37.3 \%$ & $39.8 \%$ & $42.4 \%$ & $45.2 \%$ & $48.3 \%$ \\
$2051-55$ & $28.3 \%$ & $30.2 \%$ & $32.2 \%$ & $34.3 \%$ & $37.2 \%$ & $39.6 \%$ & $42.2 \%$ & $45.0 \%$ & $48.0 \%$ \\
\hline
\end{tabular}

Even if the reforms are not sufficient to reach the equilibrium of the pension system, Tables 8 and 9 and Tables 10 and 11 (concerning respectively the rate of return on contributions and the gross replacement ratio) show the strong reduction in the generosity of the pension system induced by the application of the contribution based method.

The previous tables show another important aspect of the Dini reform. The actual situation is very convenient for self-employed workers since they receive pension benefits computed with a rule similar to salaried workers while they pay contributions on the basis of a lower rate (20\% vs. $33 \%)$. This explains the reason behind the high level of the rates on return on contributions for self-employed workers with respect to the salaried workers when the earning based method is applied, even if the replacement ratios are similar. However, when the contribution based method is applied, pension benefits are perfectly related to contributions and the replacement ratio for self-employed workers will strongly reduce.

Finally, Table 12 shows the decomposition of the pension expenditure into direct pensions, disability benefits and indirect pensions paid to salaried workers and selfemployed workers. We can see that in all the three cases the important increase in the total pension expenditure in the next decades is driven by the rise in the direct pensions paid to salaried workers while, for the other categories, the pension expenditure is essentially under control. 
Table 12: Pension expenditure / GDP.

Source: Author's calculations

\begin{tabular}{|c|c|c|c|c|c|c|c|c|c|}
\hline & & & 2001-05 & $2006-10$ & 2011-15 & $2021-25$ & 2031-35 & $2041-45$ & $2051-55$ \\
\hline \multirow{9}{*}{ Employees } & \multirow{3}{*}{ Direct pensions } & Base & $8.09 \%$ & $8.05 \%$ & $8.03 \%$ & $8.53 \%$ & $9.19 \%$ & $9.29 \%$ & $8.50 \%$ \\
\hline & & Berl & $8.09 \%$ & $7.76 \%$ & $7.45 \%$ & $8.11 \%$ & $9.00 \%$ & $9.23 \%$ & $8.48 \%$ \\
\hline & & Prodi & $8.09 \%$ & $7.91 \%$ & $7.60 \%$ & $8.33 \%$ & $9.14 \%$ & $9.35 \%$ & $8.49 \%$ \\
\hline & \multirow{3}{*}{ Disability benefits } & Base & $0.61 \%$ & $0.61 \%$ & $0.60 \%$ & $0.62 \%$ & $0.69 \%$ & $0.72 \%$ & $0.66 \%$ \\
\hline & & Berl & $0.61 \%$ & $0.61 \%$ & $0.60 \%$ & $0.63 \%$ & $0.71 \%$ & $0.76 \%$ & $0.70 \%$ \\
\hline & & Prodi & $0.61 \%$ & $0.61 \%$ & $0.60 \%$ & $0.62 \%$ & $0.69 \%$ & $0.74 \%$ & $0.69 \%$ \\
\hline & \multirow{3}{*}{ Indirect pensions } & Base & $1.82 \%$ & $1.81 \%$ & $1.81 \%$ & $1.87 \%$ & $2.08 \%$ & $2.19 \%$ & $2.03 \%$ \\
\hline & & Berl & $1.82 \%$ & $1.80 \%$ & $1.79 \%$ & $1.87 \%$ & $2.13 \%$ & $2.30 \%$ & $2.15 \%$ \\
\hline & & Prodi & $1.82 \%$ & $1.81 \%$ & $1.79 \%$ & $1.85 \%$ & $2.08 \%$ & $2.24 \%$ & $2.10 \%$ \\
\hline \multirow{9}{*}{ Self-employed } & \multirow{3}{*}{ Direct pensions } & Base & $1.89 \%$ & $1.89 \%$ & $1.83 \%$ & $1.80 \%$ & $1.84 \%$ & $1.82 \%$ & $1.64 \%$ \\
\hline & & Berl & $1.89 \%$ & $1.85 \%$ & $1.77 \%$ & $1.77 \%$ & $1.85 \%$ & $1.84 \%$ & $1.66 \%$ \\
\hline & & Prodi & $1.89 \%$ & $1.85 \%$ & $1.76 \%$ & $1.76 \%$ & $1.84 \%$ & $1.83 \%$ & $1.65 \%$ \\
\hline & \multirow{3}{*}{ Disability benefits } & Base & $0.26 \%$ & $0.27 \%$ & $0.26 \%$ & $0.26 \%$ & $0.29 \%$ & $0.32 \%$ & $0.30 \%$ \\
\hline & & Berl & $0.26 \%$ & $0.27 \%$ & $0.26 \%$ & $0.26 \%$ & $0.30 \%$ & $0.33 \%$ & $0.32 \%$ \\
\hline & & Prodi & $0.26 \%$ & $0.27 \%$ & $0.26 \%$ & $0.26 \%$ & $0.29 \%$ & $0.32 \%$ & $0.31 \%$ \\
\hline & \multirow{3}{*}{ Indirect pensions } & Base & $0.30 \%$ & $0.30 \%$ & $0.29 \%$ & $0.29 \%$ & $0.31 \%$ & $0.33 \%$ & $0.30 \%$ \\
\hline & & Berl & $0.30 \%$ & $0.30 \%$ & $0.29 \%$ & $0.29 \%$ & $0.32 \%$ & $0.34 \%$ & $0.32 \%$ \\
\hline & & Prodi & $0.30 \%$ & $0.30 \%$ & $0.29 \%$ & $0.29 \%$ & $0.32 \%$ & $0.33 \%$ & $0.31 \%$ \\
\hline
\end{tabular}

Finally, the evolution of pension deficits clearly affects the evolution of the income tax rate $\tau_{t}$ (see Figure 21). This is related to the fact that the income tax rate is endogenously determined at each period in order to keep constant the ratio of the public debt to GDP. By comparing Figures 19 and 21, we can note that the time paths of the income tax rate and of the ratio of pension system deficit to GDP, in the three scenarios, are very similar. For example, in the short run and medium run, recent pension reforms by reducing pension deficits, and then public deficits, authorize a reduction of the income tax rate with respect to the base scenario.

Figure 21: Income tax rate, normalized to 1 in 2001-2005

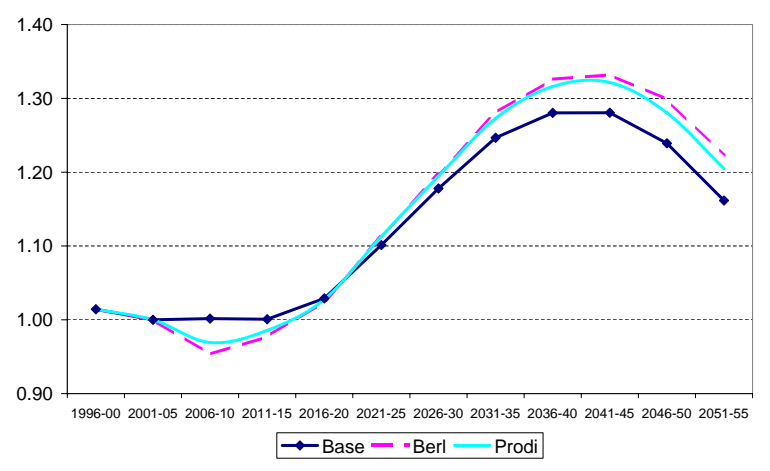




\subsection{Generational accounting}

We now use the generational accounting approach introduced by Auerbach et al. (1994) to evaluate the gains and the losses for each generation associated with the introduction of the Berlusconi and the Prodi reforms. For each generation, we compute the ratio of the expected present value of the revenues (pension benefits and per capita government expenditure) to the expected present value of the payments (income taxes and social security contributions).

As shown in Table 13, the first generation considered in the generational accounting analysis is that born in the period 1926-1930, while the last one is that born in the period 1996-2000. The analysis concerns only native salaried workers who start working at 22 .

In the base scenario, all the generations stop working at 58. In the simulation concerning the Berlusconi reform, all the generations born before 1946 stop working at 58, the generation born in the period 1946-1950 stops working at 61, and all the generations born after 1950 stop working at 62 . In the simulation concerning the Berlusconi reform, all the generations born before 1946 stop working at 58, the generation born in the period 1946-1950 stops working at 59, and all the generations born after 1950 stop working at 61 .

Table 13: Generations considered in the generational accounting analysis

\begin{tabular}{l|cc|cc|cc}
\hline & \multicolumn{2}{|c|}{ Base } & \multicolumn{2}{c|}{ Berl } & \multicolumn{2}{c}{ Prodi } \\
year of birth & retirement age & year of retiring & retirement age & year of retiring & retirement age & year of retiring \\
\hline $1926-30$ & 58 & $1984-88$ & 58 & $1984-88$ & 58 & $1984-88$ \\
$1931-35$ & 58 & $1989-93$ & 58 & $1989-93$ & 58 & $1989-93$ \\
$1936-40$ & 58 & $1994-98$ & 58 & $1994-98$ & 58 & $1994-98$ \\
$1941-45$ & 58 & $1999-03$ & 58 & $1999-03$ & 58 & $1999-03$ \\
$1946-50$ & 58 & $2004-08$ & 61 & $2007-11$ & 59 & $2005-09$ \\
$1951-55$ & 58 & $2009-13$ & 62 & $2013-17$ & 61 & $2012-16$ \\
$1956-60$ & 58 & $2014-18$ & 62 & $2018-22$ & 61 & $2017-21$ \\
$1961-65$ & 58 & $2019-23$ & 62 & $2023-27$ & 61 & $2022-26$ \\
$1966-70$ & 58 & $2024-28$ & 62 & $2028-32$ & 61 & $2027-31$ \\
$1971-75$ & 58 & $2029-33$ & 62 & $2033-37$ & 61 & $2032-36$ \\
$1976-80$ & 58 & $2034-38$ & 62 & $2038-42$ & 61 & $2037-41$ \\
$1981-85$ & 58 & $2039-43$ & 62 & $2043-47$ & 61 & $2042-46$ \\
$1986-90$ & 58 & $2044-48$ & 62 & $2048-52$ & 61 & $2047-51$ \\
$1991-95$ & 58 & $2049-53$ & 62 & $2053-57$ & 61 & $2052-56$ \\
$1996-00$ & 58 & $2054-58$ & 62 & $2058-62$ & 61 & $2057-61$ \\
\hline
\end{tabular}

The results of this analysis are shown in Figure 22. First of all, by considering the base case, we note that the value of this index decreases starting from the generation 
born in the period 1956-1960. The reason of this decrease is the reduction of the generosity of the pension system related to the introduction of the pro-rata method and the contribution based method, and the strong increase in the income tax rate necessary to keep constant the ratio between the public debt and the GDP (see Figure 21).

With respect to the base case, the Berlusconi reform causes a sharp fall of the index for the generation born in 1946-1950, which is the first generation who must work until 61, while with the Prodi reform the reduction of the index begins for the generation born in 1951-1955. It is important to note that the generations born in the periods 1946-1950 and 1951-1955 are the first generations forced to pay more contributions and they receive a pension computed with the earning based method which implies, as we have already seen, that the increase in the value of their pension benefit is not much important. In contrast, the following generations are forced to pay more contributions, but receive a pension benefit computed with the pro-rata method or the contribution based method; for these generations, therefore, the increase in pension benefits is more significant and the difference between the three indexes tends to shrink. Observe, however, that the value of the index remains significantly lower with respect to the base case in the scenarios with increased retirement age.

Figure 22: Expected present value of revenues / Expected present value of payments

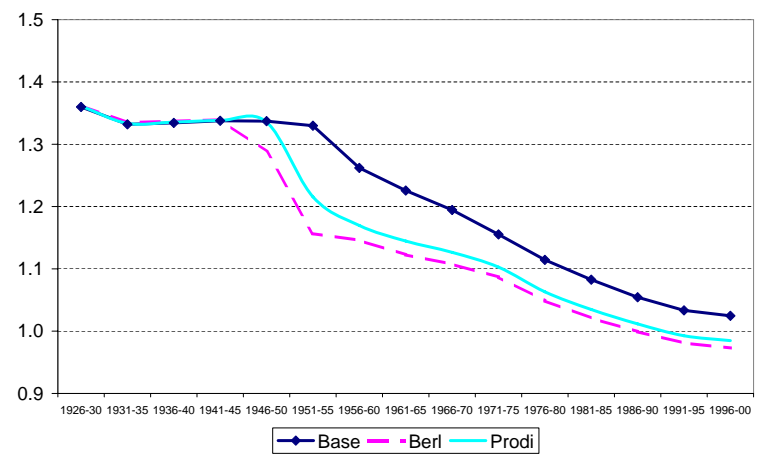

We can conclude that the Berlusconi and the Prodi reforms have a positive impact on the pension system in the medium term but, after 2040, they appear completely ineffective: the increase in the retirement age does not induce a reduction of pension system deficits, which remain of about $1.7 \%$ of GDP. Moreover, these reforms imply important losses for the next generations. 


\section{SENSITIVITY ANALYSIS}

\subsection{Immigration}

We now analyze the robustness of our results concerning the Prodi reform introduced in 2007. The first element of uncertainty that we consider concerns the demographic evolution by focusing on the role played by immigration. The base case assumes that immigrants of the second generation have the same fertility rates as natives. We consider here the case in which immigrants of the second generation have the same fertility rates as their parents, i.e. the double of fertility rates compared to the natives. As Figures 23 and 24 show, this scenario has important effects on the demographic evolution by reducing the old-age dependency ratio and by increasing the working age population.

Figure 23: Old-age dependency ratio

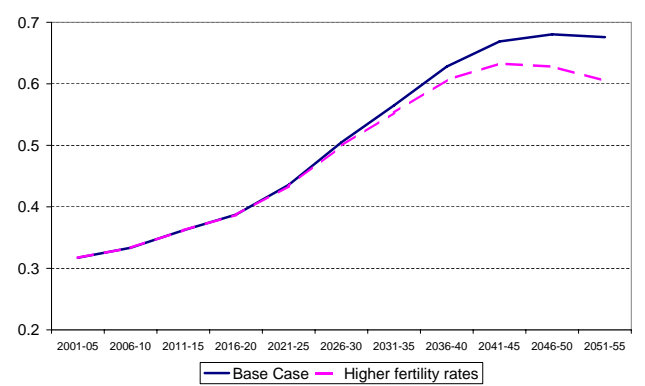

Figure 24: Working age population

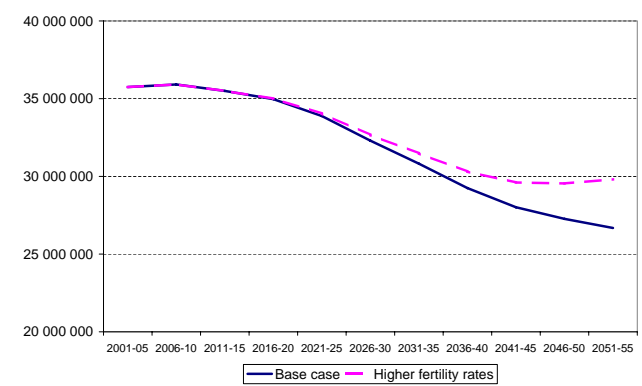

Even if this scenario implies, with respect to the Prodi reform, a reduction in future wages induced by the increase in the labour supply (see Figures 25 and 26), it determines an important reduction of the ratio between the pension system deficits and GDP since 2030 (Figure 27). In particular, this scenario implies in 2055 a reduction of this ratio of about 0.5 percentage points. 
Figure 25: Employment rate

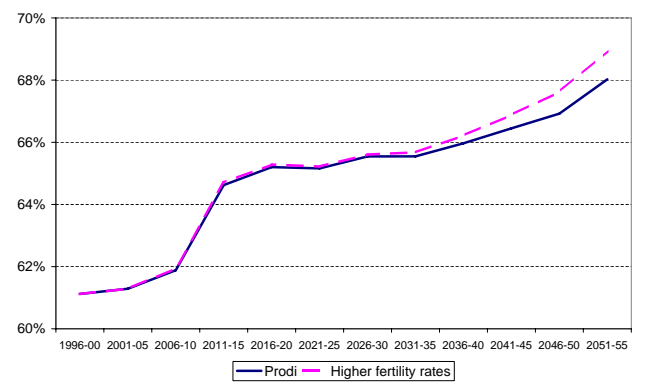

Figure 26: Wage, per unit of effective labor

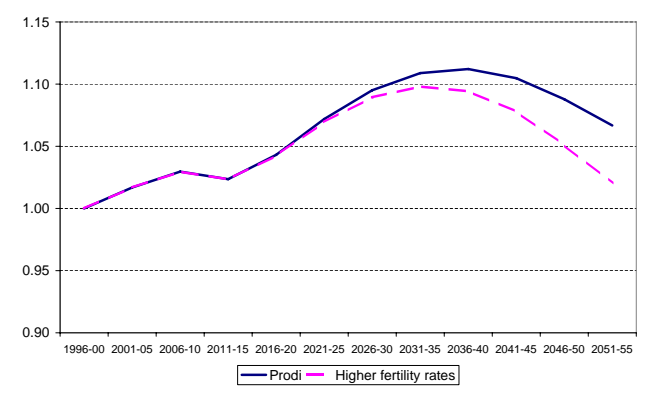

Figure 27: Pension system deficit / GDP

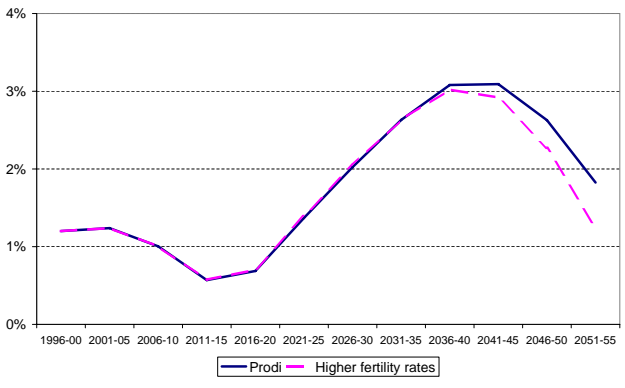

The previous simulation shows the importance of immigration as a key element that affects the sustainability of the pension system. As a consequence, we can imagine immigration as a policy tool that could be used in order to balance the pension system in the long run.

We consider here a scenario in which additional migrants enter Italy starting from the period 2026-2030. In particular, in the periods 2026-2030 and 2051-2055, we assume 250,000 additional immigrants per year, while between 2031 and 2050 (i.e. when the size of pension deficits is larger) we suppose more important flows, as shown in Figure 28. 
Figure 28: Number of yearly immigrants

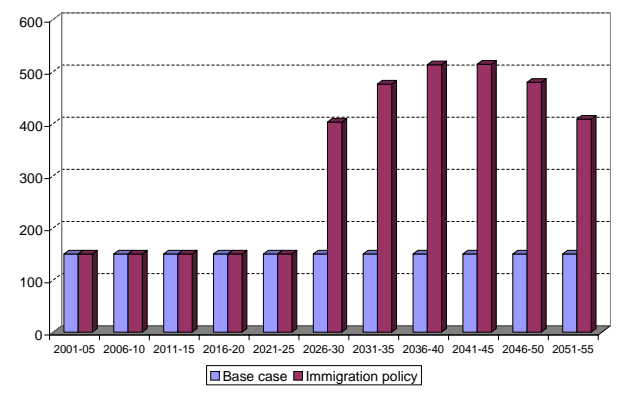

Figures 29 and 30 show the demographic implications of this policy: the increase of the weight of immigrants on the total population (more than $30 \%$ vs. $18 \%$ in the base case) and the reduction of the old-age dependency ratio.

Figure 29: Immigrants / Total population

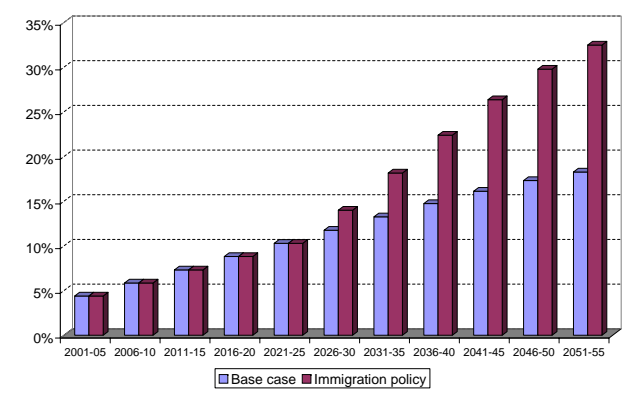

Figure 30: Old-age dependency ratio

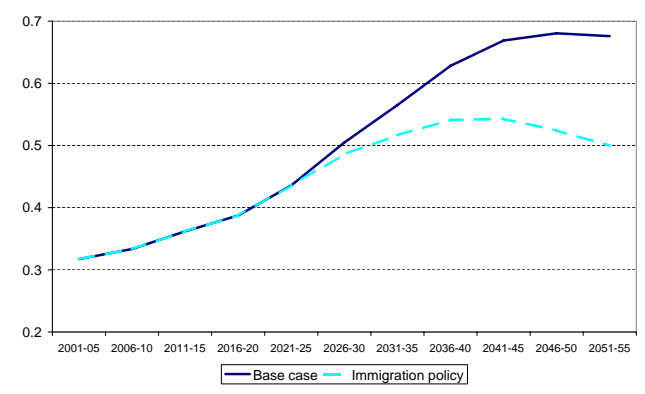

The economic effects of this reform are many. The effect on the GDP growth rate (Figure 31) is positive from the period 2026-2030 onwards, i.e. since the immigration policy is applied. Before, the negative effect on economic growth is related to an expectation mechanism. Individuals, indeed, expect a future reduction in tax levels thanks to the reduction in pension deficits due to the immigration policy. The increase in future expected incomes induces individuals, when the information is available (in the period 2006-2010), to increase consumption and leisure demand. The reduction of savings (and thus of capital accumulation) and of labor supply explain the initial reduction of GDP growth rate. Moreover, by stimulating labor supply, this policy reduces wages with respect to the base case (Figure 32).

Another important economic aspect is the effect on the productivity growth rate that 
depends on the weighted average of the stocks of human capital of each age class working at the same period (see Equation (6)). Given that immigrants are supposed to be less productive than natives, the immigration policy has a negative effect on the productivity growth rate, as shown in Figure 33. In particular, in 2055, the difference would be equal to $0.16 \%$.

The effects on the pension system (see Figure 34 ) are positive starting from the period 2026-2030 and the immigration policy allows to balance the pension system in 2055. Before 2025, the negative effect is explained by the evolution of GDP in the first periods.

Figure 31: GDP growth rate

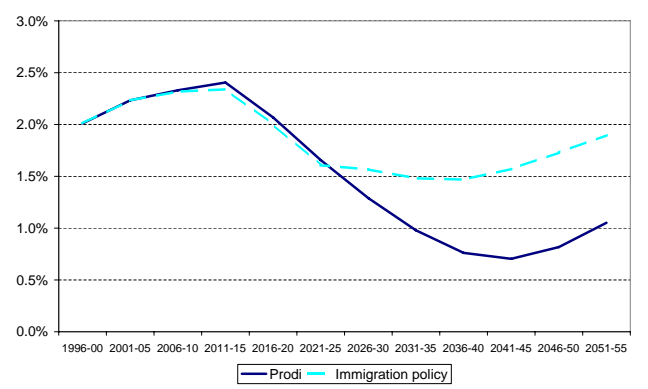

Figure 33: Productivity growth rate

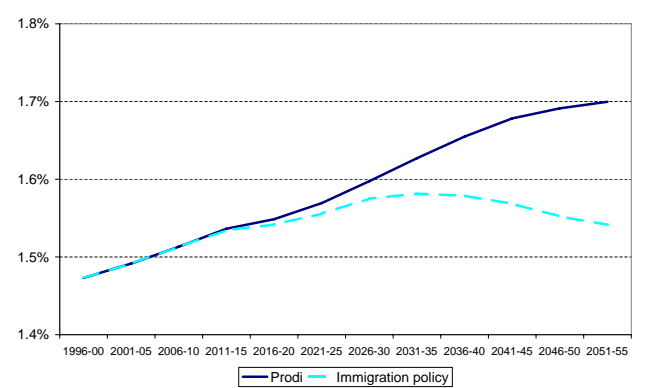

Figure 32: Wage, per unit of effective labor

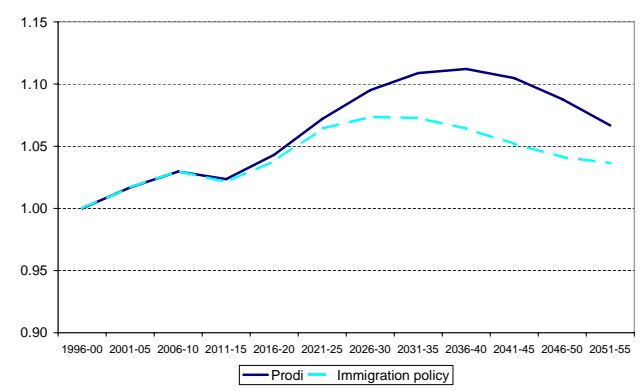

Figure 34: Pension system deficit / GDP

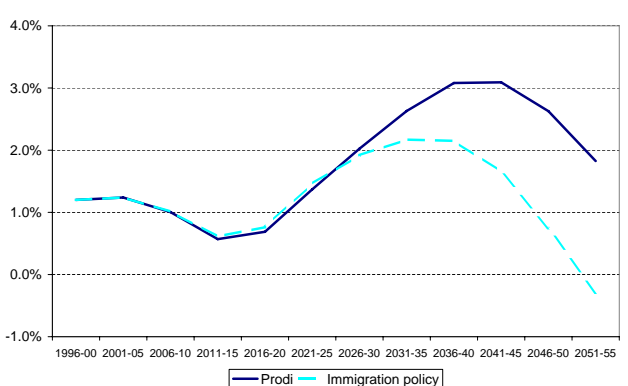




\subsection{Pension benefits}

One important element of uncertainty in our simulation exercise concerns the value of pension benefits. The uncertainty is related to the fact that the Dini reform (Law 335/1995) states that the transformation coefficients used in the computation of pension benefits, with the contribution based method and the pro-rata method, must be updated every ten years according to economic and demographic evolutions, in particular the increase in life expectancy. In 2005, i.e. ten years after the introduction of the Dini reform, no revision of the transformation coefficients were made, reflecting the enormous difficulty in the Italian political context, to reform the pension system penalizing the retirees.

However, in 2007, the Prodi reform (Law 247/2007) appointed a commission of ten experts supposed to propose new criteria for the determination of the transformation coefficients, by December 2008. The new criteria would take into account the macroeconomic and demographic evolutions, the relationship between life expectancy and retirement age, and the persistency of career paths. At the same time the Law 247/2007 introduced new transformation coefficients that thus replace those of $1995 .{ }^{23}$ Given that these new coefficients will be applied with the pro-rata method, i.e. starting from 2015 , and given the pressure that the national trade unions will exert in next years, the probability that they will be effectively applied without any modifications before 2015 is not so high in our opinion.

In the following simulation we compare the Prodi scenario with a scenario in which we assume that the new coefficients introduced by the Law 247/2007 will effectively replace the previous ones. As shown in Table 14, the new coefficients are from 6 to $8 \%$ lower than the previous ones, implying a reduction in the same proportion in pension benefits.

\footnotetext{
${ }^{23}$ The new coefficients are computed by considering data about life expectancy of 2002 (instead of 1990), probabilities to die leaving survivors of 2002 (instead of 1989), surviving spouse's probabilities to die or to get new marriage of 2002 (instead of 1990).
} 
Table 14: Transformation coefficients (Law 335/1995 and Law 247/2007)

\begin{tabular}{llll}
\hline & Old coefficients & New coefficients & $\%$ variation \\
\hline 57 & $4.720 \%$ & $4.419 \%$ & $-6.4 \%$ \\
58 & $4.860 \%$ & $4.538 \%$ & $-6.6 \%$ \\
59 & $5.006 \%$ & $4.664 \%$ & $-6.8 \%$ \\
60 & $5.163 \%$ & $4.798 \%$ & $-7.1 \%$ \\
61 & $5.334 \%$ & $4.940 \%$ & $-7.4 \%$ \\
62 & $5.514 \%$ & $5.093 \%$ & $-7.6 \%$ \\
63 & $5.706 \%$ & $5.257 \%$ & $-7.9 \%$ \\
64 & $5.911 \%$ & $5.432 \%$ & $-8.1 \%$ \\
65 & $6.136 \%$ & $5.620 \%$ & $-8.4 \%$ \\
\hline
\end{tabular}

The macroeconomic effects of a reduction of the generosity of a PAYGO pension system are well known: the forward looking behavior together with the rational expectations hypothesis imply that, when the information is available, agents react to a future reduction in pension benefits by saving more. This induces a better evolution of the ratio between investments and GDP (Figure 35), a greater capital accumulation and a greater economic growth (Figure 36).

Figure 35: Investments / GDP

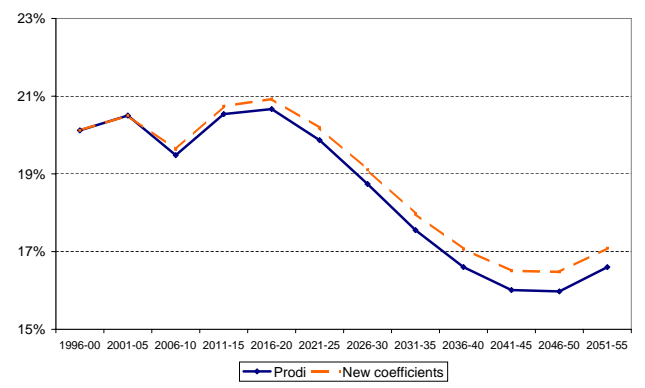

Figure 36: GDP growth rate

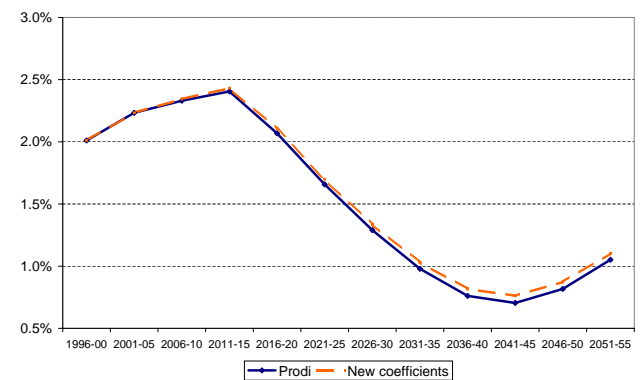

The simulation exercise shows (see Figures 37 and 38) that the revision of the transformation coefficients is a good tool in order to guarantee the sustainability of the pension system. In 2055, the pension system deficit would be equal to $0.8 \%$ of GDP, i.e. a half than in the base case. This result suggests that further revisions of the transformation coefficients would permit to completely solve the financial problems of the Italian pension system.

Clearly, from a political point of view, the problem is that such a policy implies that the burden is completely born by the retirees. Table 15 compares, for native salaried 
Figure 37: Pension system deficit / GDP

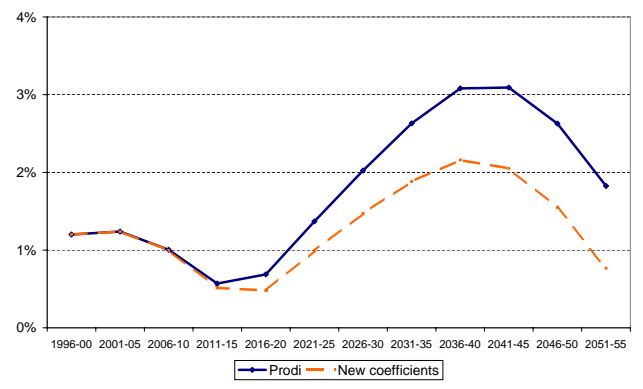

Figure 38: Pension system expenditure / GDP

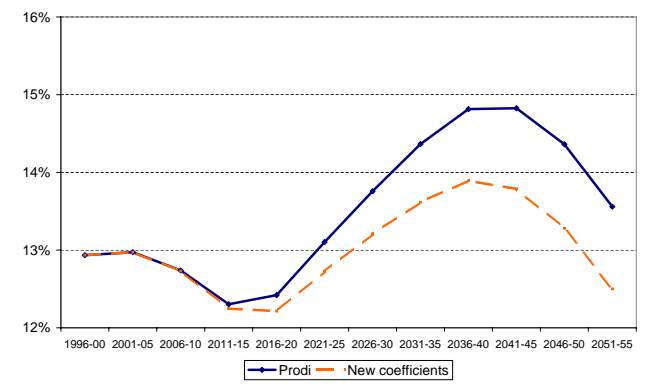

workers, the replacement ratios with and without the revision of the transformation coefficients. For example, in 2055, the reduction of the replacement ratio would be $7 \%$ for those who retire at $61,7.5 \%$ for those who retire at 63 , and $8 \%$ for those who retire at 65 . Note that the percentage reductions in the replacement ratios are a little bit less important with respect to the ones displayed in Table 15. This is related to the fact that the reduction of the generosity of the pension system induces a better evolution of wages and GDP allowing a (small) positive effect on pension benefits that partially compensates for the reduction of the transformation coefficients.

Table 15: Gross replacement ratio; native employees. Source: Author's calculations

\begin{tabular}{|c|c|c|c|c|c|c|c|c|c|}
\hline \multirow{2}{*}{$\begin{array}{l}\text { Retirement age } \\
\text { Years of contributions }\end{array}$} & \multicolumn{3}{|c|}{61} & \multicolumn{3}{|c|}{63} & \multicolumn{3}{|c|}{65} \\
\hline & & 39 & & & 41 & & & 43 & \\
\hline & Prodi & New coeff & $\%$ variation & Prodi & New coeff & $\%$ variation & Prodi & New coeff & $\%$ variation \\
\hline 2006-10 & $77.5 \%$ & $77.5 \%$ & $0.0 \%$ & $82.1 \%$ & $82.1 \%$ & $0.0 \%$ & $86.8 \%$ & $86.8 \%$ & $0.0 \%$ \\
\hline 2011-15 & $77.5 \%$ & $77.5 \%$ & $0.0 \%$ & $81.8 \%$ & $81.8 \%$ & $0.0 \%$ & $86.1 \%$ & $86.2 \%$ & $0.1 \%$ \\
\hline 2016-20 & $75.9 \%$ & $72.9 \%$ & $-4.0 \%$ & $83.2 \%$ & $79.4 \%$ & $-4.6 \%$ & $91.6 \%$ & $86.9 \%$ & $-5.2 \%$ \\
\hline $2021-25$ & $74.4 \%$ & $70.7 \%$ & $-4.9 \%$ & $82.4 \%$ & $77.9 \%$ & $-5.5 \%$ & $91.7 \%$ & $86.2 \%$ & $-6.1 \%$ \\
\hline 2026-30 & $71.5 \%$ & $67.4 \%$ & $-5.8 \%$ & $80.1 \%$ & $75.0 \%$ & $-6.3 \%$ & $89.8 \%$ & $83.6 \%$ & $-6.9 \%$ \\
\hline 2031-35 & $69.3 \%$ & $64.4 \%$ & $-7.2 \%$ & $78.6 \%$ & $72.6 \%$ & $-7.6 \%$ & $89.4 \%$ & $82.1 \%$ & $-8.2 \%$ \\
\hline $2036-40$ & $66.8 \%$ & $62.1 \%$ & $-7.1 \%$ & $75.9 \%$ & $70.1 \%$ & $-7.6 \%$ & $86.4 \%$ & $79.3 \%$ & $-8.1 \%$ \\
\hline 2041-45 & $63.0 \%$ & $58.7 \%$ & $-6.7 \%$ & $71.6 \%$ & $66.4 \%$ & $-7.2 \%$ & $81.5 \%$ & $75.2 \%$ & $-7.8 \%$ \\
\hline 2046-50 & $61.9 \%$ & $57.8 \%$ & $-6.6 \%$ & $70.4 \%$ & $65.3 \%$ & $-7.1 \%$ & $80.1 \%$ & $73.9 \%$ & $-7.7 \%$ \\
\hline 2051-55 & $61.8 \%$ & $57.5 \%$ & $-7.0 \%$ & $70.2 \%$ & $65.0 \%$ & $-7.5 \%$ & $79.9 \%$ & $73.5 \%$ & $-8.0 \%$ \\
\hline
\end{tabular}

However, a generational accounting analysis (Figure 39) shows that the reduction in pension benefits does not penalize future generations with respect to the Prodi scenario, i.e. without the revision of the transformation coefficients. The ratio between the expected present value of the revenues and the expected present value of 
the payments is essentially the same in the case of the revision of the transformation coefficients as in the case of the Prodi scenario without the revision. This result is due to a general equilibrium effect implied by this policy, in fact, the reduction in pension deficits originated by the revision of the transformation coefficients permits to reduce the general taxation. For future generations, the present value of the reduction in pension benefits is equal to the present value of the reduction in taxation. It is clear that if we neglect this general equilibrium effect on taxation, the revision of the coefficients would lead to an important loss for future generations.

Figure 39: Expected present value of revenues / Expected present value of payments

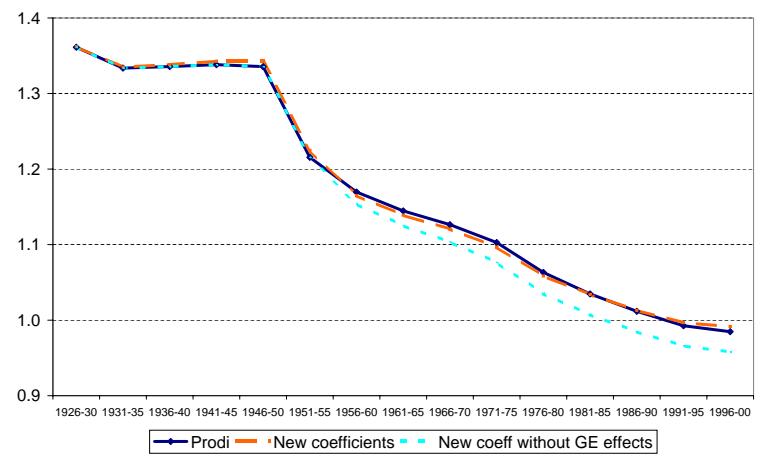

\subsection{Small open economy}

In the previous sections we made the assumption that Italy is a closed economy. Thus, the interest rate was endogenously determined in the domestic capital market in order to equalize the domestic demand and supply of capital. The choice of a closedeconomy context was related to the fact that all developed countries face an important ageing phenomenon that will deeply affect the world interest rate. Consequently, the small-open-economy assumption, that underlies a fixed interest rate at a constant world level, is not adequate in an ageing context.

However, in a context of globalized financial markets, one can seemingly state that the closed-economy assumption is also not plausible. One possible solution is to consider Italy a small open economy and to fix the interest rate at a level compatible with a world ageing context.

In this section, we assume that the evolution of the interest rate generated in our base case is compatible with a world ageing context. We simulate again the Berlusconi 
and Prodi reforms by assuming that Italy is a small open economy where the interest rate is fixed at the level computed in the base scenario.

As we have already seen in a closed-economy context, the Berlusconi and Prodi reforms induce an increase in the domestic interest rate (see Figure 12) since the increase in the retirement age stimulates the labor supply and reduces savings. Accordingly, when the Italian economy is open, it is straightforward to understand how capital moves. In the new simulations, the interest rate is fixed at the level obtained in the base case. This implies that foreign capitals must enter Italy in order to increase capital supply and equalize the net domestic interest rate at the world level. Figure 40 shows the evolution of the importance of the foreign assets in financing physical capital and bonds in the Berlusconi and Prodi scenarios. ${ }^{24}$

Figure 40: Cumulated capital inflows as a proportion of total assets

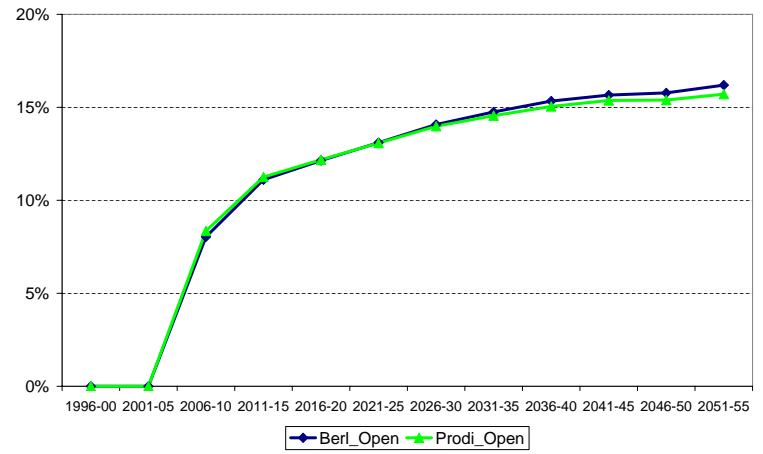

In what follows, the analysis is carried out by comparing the base scenario and the Prodi scenario (both in a closed-economy context) with the Prodi scenario in an openeconomy context. ${ }^{25}$

The macroeconomic effect of increasing the retirement age when the economy is open is very positive for the following reasons:

- The capital inflows from the rest of the world (necessary to keep the ratio capital/labour and the interest rate at the level computed in the base scenario) allow for an important additional accumulation of physical capital.

\footnotetext{
${ }^{24}$ In an open economy, the assets demanded by the firms and the government are financed not only by the aggregate household wealth but also by foreign assets.

${ }^{25}$ The results concerning the Berlusconi reform (both in a closed and in an open economy) are not represented here because the effects of opening the economy when the Berlusconi reform is applied are very similar to the effects when the Prodi reform is applied.
} 
- The Prodi reform, by increasing the retirement age, induces an increase in the employment rate. In a closed economy, the increase in the employment rate is partially compensated by the decrease (with respect to the base case) in the wage per unit of effective labor, that induces an increase in the demand for leisure. On the contrary, in an open economy, the wage per unit of effective labor remains equal to the level in the base case. This implies that the demand for leisure does not increase and explains the reason behind the very high positive effect on employment compared to the closed scenario (see Figure 41).

- The increase in the retirement age, and thus in the overall lifetime spent working, induces young people to devote additional time to human capital accumulation. In a closed economy, the positive effect in human capital accumulation is partially compensated by the decrease (with respect to the base case) in future wages per unit of effective labor and the increase in future interest rates since they reduce the present value of future gains obtained with the investment in education. On the contrary, in an open economy, the wage per unit of effective labor and the interest rate remain equal to the level in the base case. This implies that the partial compensation does not operate and explains the highly positive effect on human capital accumulation (see Figure 42). The greater investment in human capital implies a positive impact on the evolution of the productivity growth rate (see Figure 43).

Figure 41: Employment rate

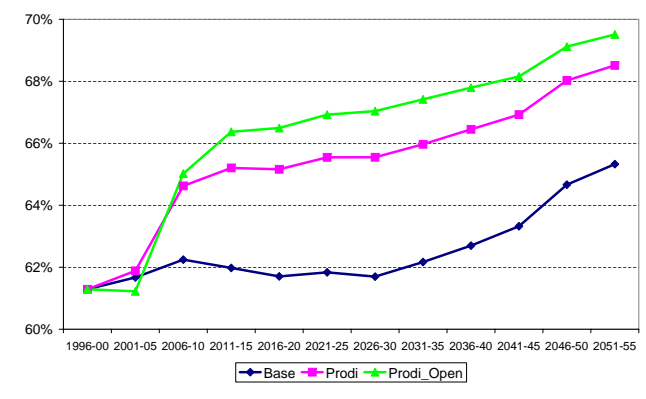


Figure 42: Time devoted to schooling

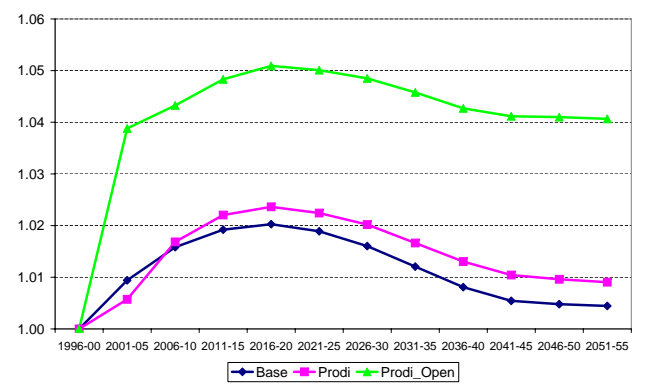

Figure 43: Productivity growth rate

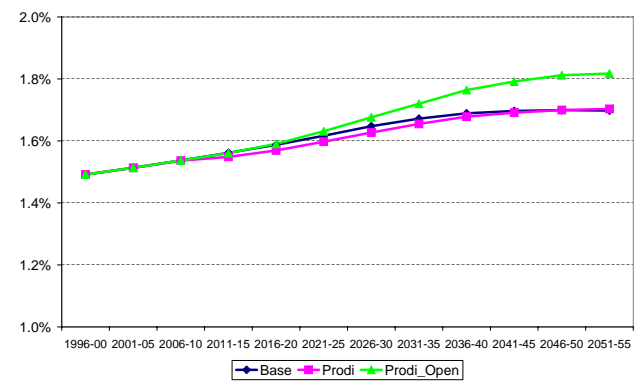

The analysis of the Prodi reform in an open-economy context with respect to a closedeconomy scenario shows a better evolution of the employment rate and a productivity growth rate. Moreover, given the importance of foreign assets inflows, the effect on economic growth will also be very positive. Figure 44 shows the effect on the GDP growth rate.

Figure 44: GDP growth rate

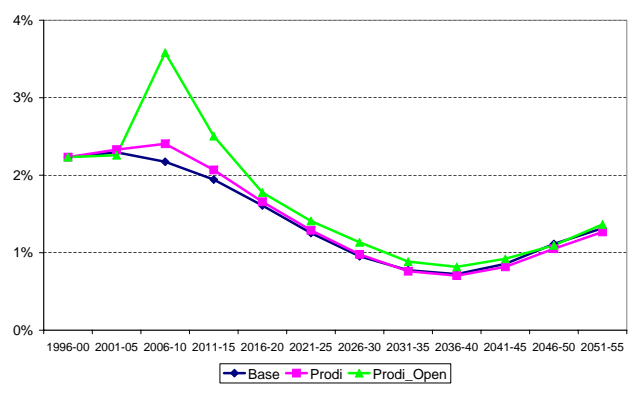

Furthermore, even in terms of pensions financing, the effects of increasing retirement age in a context of open economy is positive (see Figure 45). This is not due to a reduction in the generosity of the pension system, but to the very important increase in GDP. ${ }^{26}$ However, we can note that, even in this favorable scenario, the deficit of the pension system will sharply increase between 2015 and 2040.

\footnotetext{
${ }^{26}$ In fact, as shown in Table 16, the replacement ratios in the open economy scenario increase with respect to the closed economy scenario.
} 
Figure 45: Pension system deficit / GDP

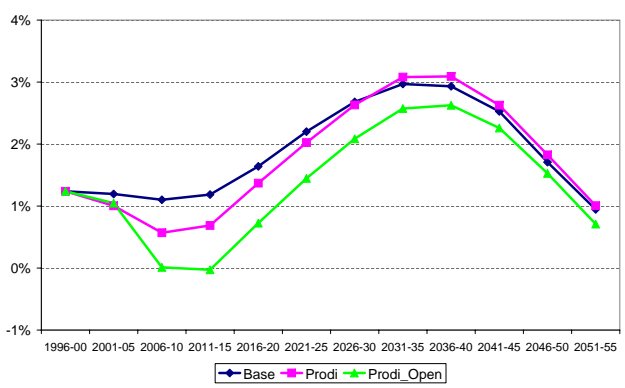

Table 16: Gross replacement ratio; native employees. Source: Author's calculations

\begin{tabular}{|c|c|c|c|c|c|c|c|c|c|}
\hline \multirow{3}{*}{$\begin{array}{l}\text { Retirement age } \\
\text { Years of contributions }\end{array}$} & \multirow{2}{*}{\multicolumn{3}{|c|}{$\begin{array}{l}61 \\
39\end{array}$}} & \multirow{2}{*}{\multicolumn{3}{|c|}{$\begin{array}{l}63 \\
41\end{array}$}} & \multirow{2}{*}{\multicolumn{3}{|c|}{$\begin{array}{l}65 \\
43\end{array}$}} \\
\hline & & & & & & & & & \\
\hline & Prodi_closed & Prodi_open & $\%$ variation & Prodi_closed & Prodi_open & $\%$ variation & Prodi_closed & Prodi_open & $\%$ variation \\
\hline 1996-00 & $77.8 \%$ & $77.8 \%$ & $0.0 \%$ & $82.3 \%$ & $82.3 \%$ & $0.0 \%$ & $86.8 \%$ & $86.8 \%$ & $0.0 \%$ \\
\hline 2001-05 & $77.5 \%$ & $77.5 \%$ & $0.0 \%$ & $82.1 \%$ & $82.2 \%$ & $0.1 \%$ & $86.8 \%$ & $86.9 \%$ & $0.1 \%$ \\
\hline 2006-10 & $77.5 \%$ & $77.7 \%$ & $0.2 \%$ & $81.8 \%$ & $82.6 \%$ & $0.8 \%$ & $86.1 \%$ & $87.6 \%$ & $1.5 \%$ \\
\hline $2011-15$ & $75.9 \%$ & $76.2 \%$ & $0.3 \%$ & $83.2 \%$ & $83.9 \%$ & $0.6 \%$ & $91.6 \%$ & $92.6 \%$ & $1.0 \%$ \\
\hline 2016-20 & $74.4 \%$ & $75.7 \%$ & $1.3 \%$ & $82.4 \%$ & $83.9 \%$ & $1.5 \%$ & $91.7 \%$ & $93.4 \%$ & $1.6 \%$ \\
\hline $2021-25$ & $71.5 \%$ & $73.2 \%$ & $1.6 \%$ & $80.1 \%$ & $81.8 \%$ & $1.7 \%$ & $89.8 \%$ & $91.7 \%$ & $1.9 \%$ \\
\hline 2026-30 & $69.3 \%$ & $71.2 \%$ & $1.8 \%$ & $78.6 \%$ & $80.6 \%$ & $2.0 \%$ & $89.4 \%$ & $91.5 \%$ & $2.1 \%$ \\
\hline 2031-35 & $66.8 \%$ & $68.5 \%$ & $1.7 \%$ & $75.9 \%$ & $77.7 \%$ & $1.8 \%$ & $86.4 \%$ & $88.3 \%$ & $2.0 \%$ \\
\hline $2036-40$ & $63.0 \%$ & $66.5 \%$ & $3.5 \%$ & $71.6 \%$ & $75.5 \%$ & $3.9 \%$ & $81.5 \%$ & $85.9 \%$ & $4.4 \%$ \\
\hline $2041-45$ & $61.9 \%$ & $64.5 \%$ & $2.6 \%$ & $70.4 \%$ & $73.3 \%$ & $2.9 \%$ & $80.1 \%$ & $83.4 \%$ & $3.3 \%$ \\
\hline 2046-50 & $61.8 \%$ & $62.0 \%$ & $0.2 \%$ & $70.2 \%$ & $70.4 \%$ & $0.2 \%$ & $79.9 \%$ & $80.1 \%$ & $0.2 \%$ \\
\hline
\end{tabular}

To sum, in the case of open economy, the introduction of a reform that increases the retirement age has very positive effects. This pension reform, in fact, involves capital inflows from the rest of the world that stimulate economic growth and reduce the ratio of pension deficits to GDP, by implying that pension imbalances are now financed by the rest of world. Of course this analysis is correct only if we assume that the rest of the world does not carry out similar pension reforms. On the contrary, if also the rest of the world increases the retirement age, the world interest rate increases (more or less as the Italian interest rate in the case of closed economy) and this implies no foreign capital flows towards Italy. Hence, the closed-economy and small-openeconomy cases should be considered as extreme scenarios that define the range of possible outcomes for Italy. 


\section{Conclusions}

The reforms introduced during the Nineties (the Amato reform in 1992 and the Dini reform in 1995) imply a strong penalization for people who pay low amounts of contributions (in particular people who retire at 57 and self-employed workers). However, these reforms fail to ensure long-run solvability of the Italian pension system and, during the transition phase, the pension system would produce deficits as high as 3-5\% of GDP. For this reason, in 2004, the Berlusconi government introduced a reform that increases the minimum retirement age to 60 years after 2008. In 2007, the Prodi government replaced the previous reform by a softer one implying that the minimum retirement age is fixed at 58 from 2008 and will gradually increase over time up to 62 .

The objective of this paper is to provide an evaluation of the impacts of these reforms by using an applied overlapping-generations general equilibrium model. We show that the increase in the retirement age will induce a significant improvement of the financial conditions of the pension system, but only in the short and in the medium run. After 2040, the positive effect related to the increase in the labor supply, and then in contributions paid by the workers, is compensated by the increase in the value of pension benefits perceived by people forced to postpone retirement. The increase in the retirement age has no positive impact on the financial conditions of the pension system from 2045 onwards, and the pension deficit remains at about $1.7 \%$ of GDP in 2055.

From the point of view of equity among generations, the generational accounting approach shows that, with respect to the base scenario, the increase in the retirement age will cause an important loss for the generations forced to work more, especially for the generations born in the periods 1946-1950 and 1951-1955 who receive pension benefits computed with the earning based method.

We have also shown the sensitivity of our results to the hypothesis concerning immigration. In particular, we analyzed a scenario in which also the second-generation immigrants display fertility rates higher than those of natives, and a scenario in which the government introduces an ambitious immigration policy. In both cases, immigration permits to reduce the old-age dependency ratio and can be seen as an instrument that can be used to guarantee the long-term solvability of the pension system.

Then we analyzed an important aspect of the Dini reform (1995). The transformation coefficients used in the computation of the pension benefits with the pro-rata method and the contribution based method are supposed to be updated every ten years according to the evolution of many elements, especially the increase in life expectancy. In 
2005, i.e. when the first revision would have been made and near national elections, nothing happened. In 2007, the Prodi government proposed new (reduced) transformation coefficients, but (i) at the same time the Prodi reform appointed a commission that will propose before December 2008 new criteria for the determination of the transformation coefficients (ii) the transformation coefficients will be applied starting from 2015, i.e. with the pro-rata method. This suggests that the new transformation coefficients are likely to be modified before 2015. In any case, we have shown that the transformation coefficients proposed with the Prodi reform would permit a strong reduction in pension deficits. Moreover, even if this implies important income losses for the retirees, a generational accounting analysis shown that the future generations will not be penalized, since the loss in pension benefits will be compensated by a lower taxation.

In the last sensitivity analysis, Italy is treated as a small open economy. By assuming that the evolution of the interest rate generated in the base scenario is compatible with a world ageing context, we simulated the Prodi reform in a small-open-economy scenario where the interest rate is exogenously fixed and the saving-investment gap is filled by international capital flows. We show that, with respect to the closedeconomy scenario, the increase of the retirement age in a small-open-economy scenario allows an important increase in the economic activity and a reduction of the ratio of pension deficits to GDP. However, even in this favorable scenario, the deficit of the pension system increases by $1.5 \%$ of GDP by 2030 horizon compared to 20012005 (hence the deficit is more than doubled).

Finally, if we compare the Italian case (where the population ageing problem is one of the most serious in the world) to other European cases, we can see that the recent reforms introduced in Italy are very important to avoid a strong increase in pension expenditures. In general, most European countries have recently increased the minimum retirement age, introduced some forms of penalization in case of early retirement and introduced an indexation mechanism of pensions related to prices rather to wages. For instance in France, where the demographic problem is less serious than in Italy, the results of the simulations realized by Chateau et al. show that the Fillon reform, ${ }^{27}$ combined with an assumed rise in activity rates of elder workers, ensure the solvability of pension regimes in France only until 2025. After 2025, the French pension system will generate important deficits that exceed 3\% of the GDP starting from 2040. The total pension expenditure will increase constantly in the period 2005-

\footnotetext{
${ }^{27}$ The Fillon reform (2003) introduced (1) a progressive increase of the period necessary to obtain a full replacement ratio (50\% of the reference wage) from 40 to 42 years in the private sector and from 37.5 to 42 years in the public sector, (2) a change in the penalty applied to workers of the private sector and introduction of a penalty applied to workers of the public sector, (3) the indexation of public sector pensions on prices rather than wages.
} 
2050 from $12.6 \%$ to $16.6 \%$ of the GDP. Moreover, if France is considered as a closed economy, the results would be worse and the total pension expenditure could reach $17.8 \%$ of the GDP in 2055. This comparison permits to note that the reforms introduced in Italy, even if they are not sufficient to ensure the long-term equilibrium, are much more efficient than the one introduced in France, where the demographic problem is less serious than in Italy. Of course, the cost related to this greater efficiency is the strong reduction of the generosity of the Italian pension system determined by the Amato and Dini reforms. 


\section{BIBLIOGRAPHY}

Auerbach A. and Kotlikoff L. (1987), Dynamic Fiscal Policy. Cambridge University Press.

Auerbach, A., Gokhale J. and Kotlikoff L. (1994), Generational accounting: a meaningful way to evaluate fiscal policy. Journal of Economic Perspectives, 8, 73-94.

Barro R.J. (2001), Human capital and growth. American Economic Review, 91, 2. Papers and proceedings of the hundred thirteenth annual meeting of the American Economic Association, 12-17.

Börsch-Supan A., Ludwing A. and Winter A. (2006), Ageing, pension reform and capital flows. Economica, 73; 625-658.

Bouzahzaha M., de la Croix D. and Docquier F. (2002), Policy reforms and growth in computable OLG economies. Journal of Economic Dynamics and Control, 26, 2093-2113.

Chateau J., Chojnicki X. and Magnani R. (2008), Disparities in pension system and financial flows among European countries. Journal of Pension Economics and Finance, Forthcoming.

European Commission and Eurostat (2002), The social situation in the European Union.

Fougère M. and Mérette M. (1999), Population ageing and economic growth in seven OECD countries. Economic Modelling, 16, 411-427.

Hviding K and Mérette M. (2001), Macroeconomic effects of pension reforms in the context of ageing populations: overlapping general equilibrium model simulations for seven OECD countries. OECD Economics Department Working Papers 1998.

Istat (2008), Spesa delle Amministrazioni pubbliche per funzione. Anni 1990-2006.

Istat (1998), Tavole di mortalità per provincia e regione di residenza.

Istat (2006), Previsioni demografiche nazionali. $1^{\circ}$ gennaio $2005-1^{\circ}$ gennaio 2050.

Istat (2007), Statistiche della previdenza e dell'assistenza sociale. I trattamenti pensionistici. Anno 2005.

Istat (2004), La presenza straniera in Italia: caratteristiche socio-demografiche. Permessi di soggiorno al 1 gennaio degli anni 2001, 2002, 2003.

Istat (2007), La popolazione straniera residente in Italia al 1 gennaio 2007.

Lucas R.J (1988), On the mechanics of economic development. Journal of Monetary Economics, 22, 3-42.

Magnani R. (2006), Vieillissement de la population en Italie et efficacité des réformes Amato et Dini : un modèle d'équilibre général à générations imbriquées. Recherches Economiques de Louvain, 72 (3), 287-338. 
Mayer J. and Riphahn R. (1999), Fertility assimilation of immigrants: evidence from count data models. IZA Discussion Paper 1999, 52.

Miles D. (1999), Modelling the impact of demographic change upon the economy. The Economic Journal, 109, 1-36.

Nucleo di Valutazione della Spesa Previdenziale (2006), Gli andamenti finanziari del sistema pensionistico obbligatorio.

Ragioneria Generale dello Stato (2006), Le tendenze di medio-lungo periodo del sistema pensionistico e socio-sanitario. Rapporto n. 8.

Sadahiro A. and Shimasawa M. (2003), The computable overlapping generations model with an endogenous growth mechanism. Economic Modelling, 20, 1-24.

Storesletten K. (2000), Sustaining fiscal policy through immigration. Journal of Political Economy, 108, 300-323.

Yaari M.E. (1965), Uncertain lifetime, life insurance, and the theory of the consumer. Review of Economic Studies, 32, 137-150. 


\section{List of working papers released by CEPII ${ }^{1}$}

No

Title

2008-24 The Location of Japanese MNC Affiliates: Agglomeration, Spillovers and Firm Heterogeneity

2008-23 Non Linear Adjustment of the Real Exchange Rate Towards its Equilibrium Values

2008-22 Demographic Uncertainty in Europe - Implications on Macro Economic Trends and Pension Reforms - An Investigation with the INGENUE2 Model

2008-21 The Euro Effects on the Firm and Product-Level Trade Margins: Evidence from France

2008-20 The Impact of Economic Geography on Wages: Disentangling the Channels of Influence

2008-19 Do Corporate Taxes Reduce Productivity and Investment at the Firm Level? Cross-Country Evidence from the Amadeus Dataset

2008-18 Choosing Sensitive Agricultural Products in Trade Negotiations

2008-17 Government Consumption Volatility and Country Size

2008-16 Inherited or Earned? Performance of Foreign Banks in Central and Eastern Europe

2008-15 The Effect of Foreign Bank Entry on the Cost of Credit in Transition Economies. Which Borrowers Benefit most?

2008-14 Contagion in the Credit Default Swap Market: The Case of the GM and Ford Crisis in 2005

2008-13 Exporting to Insecure Markets: A Firm-Level Analysis

2008-12 Social Competition and Firms' Location Choices

\section{Authors}

T. Inui, T. Matsuura \& S. Poncet

S. Béreau, A. Lopez Villavicencio \&

V. Mignon

M. Aglietta \& V. Borgy

A. Berthou \&

L. Fontagné

L. Hering \& S. Poncet

J. Arnold \&

C. Schwellnus

S. Jean, D. Laborde \&

W. Martin

D. Furceri \&

M. Poplawski Ribeiro

O. H avrylchyk \&

E. Jurzyk

H. Degryse, O. Havrylchyk,

E. Jurzyk \& S. Kozak

V. Coudert \& M. Gex

M. Crozet, P. Koenig \&

V. Rebeyrol

V. Delbecque, I. Méjean \& L. Patureau

\footnotetext{
${ }^{1}$ Working papers are circulated free of charge as far as stocks are available; thank you to send your request to CEPII, Sylvie Hurion, 9, rue Georges-Pitard, 75015 Paris, or by fax : (33) 0153685504 or by e-mail Hurion@cepii.fr. Also available on: Nwww.cepii.fr. Working papers with * are out of print. They can nevertheless be consulted and downloaded from this website.

Les documents de travail sont diffusés gratuitement sur demande dans la mesure des stocks disponibles. Merci d'adresser votre demande au CEPII, Sylvie Hurion, 9, rue Georges-Pitard, 75015 Paris, ou par fax : (33) 0153685504 ou par e-mail Hurion@cepii.fr. Egalement disponibles sur: IIwww.cepii.fr. Les documents de travail comportant* sont épuisés. Ils sont toutefois consultable sur le web CEPII.
} 
2008-11 Border Effects of Brazilian States

2008-10 International Trade Price Indices

2008-09 Base de données CHELEM - Commerce international du CEPII

2008-08 The Brain Drain between Knowledge-Based Economies: the European Human Capital Outflow to the US

2008-07 Currency Misalignments and Exchange Rate Regimes in Emerging and Developing Countries

2008-06 The Euro and the Intensive and Extensive Margins of Trade : Evidence from French Firm Level Data

2008-05 On the Influence of Oil Prices on Economic Activity and other Macroeconomic and Financial Variables

2008-04 An Impact Study of the EU-ACP Economic Partnership Agreements (EPAs) in the Six ACP Regions

2008-03 The Brave New World of Cross-Regionalism

2008-02 Equilibrium Exchange Rates: a Guidebook for the Euro-Dollar Rate

2008-01 How Robust are Estimated Equilibrium Exchange Rates? A Panel BEER Approach

2007-24 Testing the Finance-Growth Link: Is there a Difference between Developed and Developing Countries?

2007-23 Nonlinear Adjustment of the Real Exchange Rate Towards its Equilibrium Value : a Panel Smooth Transition Error Correction Modelling

2007-22 Economic Geography, Spatial Dependence and Income Inequality in China

2007-21 Does FDI in Manufacturing Cause FDI in Business Services ? Evidence from French Firm-Level Data

2007-20 Bilateral Trade of Cultural Goods A.C. Disdier, S.H.T. Tai

2007-19 China and India in International Trade: from
M. Daumal \&

S. Zignago

G. Gaulier, J. Martin, I. Méjean \& S. Zignago

A. de Saint Vaulry,

A. Tritah

V. Coudert

\& C. Couharde

A. Berthou

\& L. Fontagné

V. Mignon

\& F. Lescaroux

L. Fontagné, D. Laborde

\& C. Mitaritonna

A. Tovias

A. Bénassy-Quéré,

S. Béreau

\& V. Mignon

A. Bénassy-Quéré,

S. Béreau

\& V. Mignon

G. Dufrénot, V. Mignon \& A. Péguin-Feissolle

S Béreau, A. Lopez Villavicencio, V. Mignon

L. Hering \& S. Poncet

B. Nefussi \& C. Schwellnus

, L. Fontagné \& T. Mayer

F. Lemoine \& D. Ünal-Kesenci, 
Laggards to Leaders?

2007-18 How Remote is the Offshoring Threat?

K. Head, T. Mayer \& J. Ries,

2007-17 Costs and Benefits of Euro Membership: a Counterfactual Analysis

E. Dubois, J. Héricourt \&. V. Mignon

I. Méjean, L Patureau

2007-15 MIRAGE, Updated Versio of the Model for Trade Policy Analysis Focus on Agriculture and Dynamics

2007-14 Mondialisation des services de la mesure à l'analyse

2007-13 How are wages set in Beijing

2007-12 IMF Quotas at Year 2030

2007-11 FDI and Credit Constraints: Firm Level Evidence in China

2007-10 Fiscal Policy in Real Time

2007-09 Global Ageing and Macroeconomic Consequences of Demographic Uncertainty in a Multi-regional Model

2007-08 The Effect of Domestic Regulation on Services Trade Revisited

2007-07 The location of domestic and foreign production affiliates by French multinational firms

2007-06 Specialisation across Varieties within Products and North-South Competition

2007-05 Trade Costs and the Home Market Effect

2007-04 The Impact of Regulations on Agricultural Trade: Evidence from SPS and TBT Agreements

2007-03 International Comparisons of Living Standards by Equivalent Incomes

2007-02 Does Risk Aversion Drive Financial Crises? Testing the Predictive Power of Empirical Indicators

2007-01 Asian Catch Up, World Growth and International Capital Flows in the XXIst Century : A Prospective Analysis with the INGENUE 2 Model

2006-27 Current Account Reversals and Long Term Imbalances: Application to the Central and Eastern

J. Alho \& V. Borgy

C. Schwellnus

T.Mayer

I. Méjean

B. Néfussi

L. Fontagné, G. Gaulier

\& S. Zignago

M. Crozet

\& F. Trionfetti

A.-C. Disdier,

L. Fontagné

\& M. Mimouni

M. Fleurbaey \&

G. Gaulier

V. Coudert \& M. Gex

M. Aglietta, V. Borgy, J. Château, M. Juillard,

J. Le Cacheux, G. Le

Garrec \& V. Touzé

K. Benhima \& O. Havrylchyk 
European Countries

2006-26 On Legal Origins and Brankruptcy Laws: the European Experience (1808-1914)

J. Sgard

2006-25 Taux d'intérêt et marchés boursiers : une analyse empirique de l'intégration financière internationale

V. Borgy \& V. Mignon

2006-24 Changing Patterns of Domestic and Cross-Border Fiscal Policy Multipliers in Europe and the US

2006-23 Market Access Impact on Individual Wage: Evidence from China

2006-22 FDI in Chinese Cities: Spillovers and Impact on Growth

2006-21 Taux d'intérêt et marchés boursiers : une analyse empirique de l'intégration financière internationale

2006-20 World Consistent Equilibrium Exchange Rates

2006-19 Institutions and Bilateral Asset Holdings

A. Bénassy-Quéré \& J. Cimadomo

L. Hering \& S. Poncet

N. Madariaga

\& S. Poncet

V. Borgy \& V. Mignon

A. Bénassy-Quéré,

A. Lahrèche-Révil

\& V. Mignon

V. Salins

\& A. Bénassy-Quéré

2006-18 Vertical Production Networks: Evidence from France

2006-17 Import Prices, Variety and the Extensive Margin of Trade

2006-16 The Long Term Growth Prospects of the World Economy: Horizon 2050

2006-15 Economic Integration in Asia: Bilateral Free Trade Agreements Versus Asian Single Market

\& M. Fouquin

2006-14 Foreign Direct Investment in China: Reward or Remedy?

O. Havrylchyk \& S. Poncet

2006-13 Short-Term Fiscal Spillovers in a Monetary Union

2006-12 Can Firms' Location Decisions Counteract the Balassa-Samuelson Effect?

2006-11 Who's Afraid of Tax Competition? Harmless Tax Competition from the New European Member States

2006-10 A Quantitative Assessment of the Outcome of the Doha Development Agenda

A. Bénassy-Quéré

I. Méjean

A. Lahrèche-Révil

Y. Decreux \& L. Fontagné

J. Château \& X. Chojnicki

H. Boumellassa 
\& D. Ünal-Kesenci

2006-07 Deindustrialisation and the Fear of Relocations in the Industry

H. Boulhol \& L. Fontagné

C. Deubner

2006-06 A Dynamic Perspective for the Reform of the Stability and Gowth Pact

2006-05 China's Emergence and the Reorganisation of Trade Flows in Asia

G. Gaulier, F. Lemoine \& D. Ünal-Kesenci

2006-04 Who Pays China's Bank Restructuring Bill?

G. Ma 


\section{CEPII \\ DOCUMENTS DE TRAVAIL / WORKING PAPERS}

Si vous souhaitez recevoir des Documents de travail, merci de remplir le coupon-réponse ci-joint et de le retourner à :

Should you wish to receive copies of the CEPII's Working papers, just fill the reply card and return it to:

Sylvie HURION - Publications

CEPII - 9, rue Georges-Pitard - 75740 Paris - Fax : (33) 1.53.68.55.04

sylvie.hurion@cepii.fr

M./Mme / Mr./Mrs

Nom-Prénom / Name-First name ....

Titre / Title

Service / Department.

Organisme / Organisation

Adresse / Address.

Ville \& CP / City \& post code

Pays / Country ................................................................. Tél.

Your e-mail ......

Désire recevoir les Document de travail du CEPII $n^{\circ}$ :

Wish to receive the CEPII's Working Papers No:

Souhaite être placé sur la liste de diffusion permanente (pour les bibliothèques)

Wish to be placed on the standing mailing list (for Libraries). 